Discussion Paper No. 09-082

Assessing the Effects of a Road Surfacing Cartel in Switzerland

Kai Hüschelrath, Nina Leheyda, and Patrick Beschorner

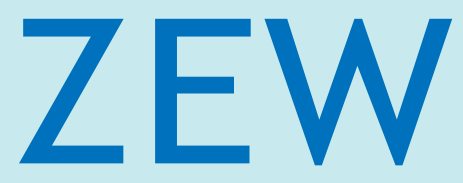

Zentrum für Europäische Wirtschaftsforschung $\mathrm{GmbH}$

Centre for European

Economic Research 
Discussion Paper No. 09-082

\title{
Assessing the Effects of a Road Surfacing Cartel in Switzerland
}

\author{
Kai Hüschelrath, Nina Leheyda, \\ and Patrick Beschorner
}

Download this ZEW Discussion Paper from our ftp server:

ftp://ftp.zew.de/pub/zew-docs/dp/dp09082.pdf

Die Discussion Papers dienen einer möglichst schnellen Verbreitung von neueren Forschungsarbeiten des ZEW. Die Beiträge liegen in alleiniger Verantwortung der Autoren und stellen nicht notwendigerweise die Meinung des ZEW dar.

Discussion Papers are intended to make results of ZEW research promptly available to other economists in order to encourage discussion and suggestions for revisions. The authors are solely responsible for the contents which do not necessarily represent the opinion of the ZEW. 


\section{Non-technical summary}

The last couple of years have seen an increasing interest in the evaluation of competition policy both in practice and in academia. With respect to the former, the Office of Fair Trading in the UK, for instance, recently started to estimate the 'positive impact' of its activities on direct benefits to consumers. In academia, recent research shows an increasing interest in special topics such as the effectiveness of merger control, the effects of competition policy interventions or the robustness of certain methods to evaluate competition policy.

Against this background, this paper assesses the impact of the detection of a hard-core cartel in the Swiss market for road surfacing on post-cartel competition. In addition to an investigation of supply-side factors, demand-side factors, and market prices, the paper also derives estimates of the economic effects of the decision. The results indicate that the detection of the cartel may have led to short-term price reductions; however, the persistent collusion-friendly industry structure forecloses larger and durable gains for the customers.

With respect to the implications of the case study for general cartel policy, one improvement possibility would be to carry out screenings to identify potentially collusionfriendly industries by using a set of collusion factors. Subsequently, these suspicious industries should then be investigated more closely focusing on market structure, market behavior and market results, possibly in the form of 'inquiries' conducted by the UK Competition Commission. Such an approach would not only raise the probability to detect cartels directly but it would also create a signal for the firms in the respective industries that they are on a watch. Ideally, one of the companies becomes nervous enough to decide to apply for leniency. 


\section{Das Wichtigste in Kürze}

In den vergangenen Jahren hat die Bedeutung einer Evaluation von Wettbewerbspolitik deutlich zugenommen - dies gilt sowohl für das praktische als auch das wissenschaftliche Umfeld. Aus praktischer Sicht hat beispielsweise das Office of Fair Trading im Vereinigten Königreich vor Kurzem damit begonnen, die positiven Wirkungen seiner Aktivitäten auf die Konsumentenwohlfahrt zu messen. Aus wissenschaftlicher Sicht zeigen jüngere Forschungsprojekte ein gesteigertes Interesse für die Betrachtung von Spezialthemen wie der Effektivität der Fusionskontrolle, den Effekten wettbewerbspolitischer Eingriffe oder der Robustheit bestimmter Methoden der Evaluation von Wettbewerbspolitik.

Vor diesem Hintergrund untersucht der vorliegende Beitrag die Auswirkungen der Aufdeckung einer Kartellabsprache im Schweizer Markt für Strassenbeläge auf den Wettbewerb. In Ergänzung zu einer Analyse der Angebots- und Nachfrageseite sowie der Marktpreisentwicklungen unternimmt der Beitrag auch eine grobe Abschätzung der möglichen ökonomischen Effekte der Entscheidung der Schweizer Wettbewerbskommission. Die Ergebnisse zeigen, dass die Entscheidung kurzfristig durchaus zu Preissenkungen beigetragen haben mag, dass aber die persistente kollusionsfreundliche Industriestruktur die Realisierung grösserer und dauerhafterer Vorteile für die Konsumenten vermutlich verhindert hat.

Im Hinblick auf die allgemeinen Implikationen der Fallstudie für die Kartellverfolgung lässt sich der Vorschlag ableiten, auf Seiten der Wettbewerbsbehörde sogenannte Screenings mit Hilfe eines Baukastens von Kollusionsfaktoren durchzuführen um auf diese Weise potentiell kollusionsgefärdete Industrien zu identifizieren. Diese Industrien sollten dann in der Folge genauer untersucht werden im Hinblick auf Anzeichen für bestehende Absprachen - womöglich in Form von sogenannten, inquiries' wie sie von der UK Competition Commission bereits seit geraumer Zeit durchgeführt werden. Die Verfolgung eines solchen Ansatzes würde nicht nur die durchschnittliche Aufdeckungswahrscheinlichkeit für Kartellabsprachen erhöhen, sondern es würden automatisch Signale an die betreffenden Industrien gesendet, dass sie unter Beobachtung stehen. Im Idealfall würde dies dazu führen, dass einige oder mehrere Unternehmen ,nervös genug' würden um sich für die Anwendung der Kronzeugenregelung zu bewerben und somit zur Aufdeckung des betreffenden Kartells aktiv beitragen. 


\title{
ASSESSING THE EFFECTS OF A ROAD SURFACING CARTEL IN SWITZERLAND
}

\author{
Kai Hüschelrath* \\ Nina Leheyda ${ }^{\infty}$ \\ Patrick Beschorner*
}

\begin{abstract}
The paper assesses the impact of the detection of a hard-core cartel in the Swiss market for road surfacing on post-cartel competition. In addition to an investigation of supply-side factors, demand-side factors, and market prices, the paper also derives estimates of the economic effects of the decision. The results indicate that the detection of the cartel may have led to short-term price reductions; however, the persistent collusion-friendly industry structure forecloses larger and durable gains for the customers.
\end{abstract}

KEYwORDS: Competition Policy, Evaluation, Cartels, Switzerland

JEL: L41, K21

\footnotetext{
* Researcher, ZEW Centre for European Economic Research, Department for Industrial Economics and International Management, Mannheim, Germany and Assistant Professor for Industrial Organizaton and Competitive Strategy, WHU Otto Beisheim School of Management, Vallendar, Germany. E-mail: hueschelrath@zew.de.

${ }^{\infty}$ Researcher, ZEW Centre for European Economic Research, Department for Industrial Economics and International Management, Mannheim, Germany.

* Senior Researcher, ZEW Centre for European Economic Research, Department for Industrial Economics and International Management, Mannheim, Germany. A preliminary version of the paper is part of a study for the Swiss State Secretariat for Economic Affairs SECO. The complete study (in German language) can be downloaded at http://www.weko.admin.ch/dokumentation/00216/index.html?lang=de. We would like to thank Sven Michal, Samuel Rutz, Frank Stüssi, Spyros Arvanitis and Martin Wörter for helpful comments on drafts of the study and Dace Lauberte and Shampa Ghosh for excellent research assistance. The usual disclaimer applies.
} 


\section{INTRODUCTION}

There is no significant doubt among economists that competition policy has established itself in most industrialized countries as an integral part of public policy that contributes substantially to the improvement of the wealth of nations. However, the follow-up question of how substantial these benefits of competition policy have been has not yet attracted huge research input by economists. This 'state of the art' is unfortunate as, for instance, competition authorities have to justify their budgets (or requests for budget increases) and might find it helpful to show the significance of their work. Furthermore, economists also benefit from showing to what extent society benefits from their public policy recommendations.

Against this background, the paper aims at assessing the question whether competition policy matters by analyzing the impact of the detection of a hard-core cartel in the Swiss market for road surfacing on post-cartel competition. In addition to an investigation of supply-side factors, demand-side factors, and market prices, the paper also derives estimates of the economic effects of the decision.

In order to reach the aim of the paper it is structured into six sections. Following this brief introduction, the second section reviews the theoretical and empirical foundations of antitrust actions against hard-core cartels. Additionally, existing evaluation studies are reviewed which try to assess the effectiveness and the impact of cartel enforcement policies. The third section describes the Swiss road surfacing cartel case with regard to the decision as well as the economically meaningful relationships of the enquiry of the Swiss Competition Commission (COMCO). Furthermore, other comparable cases in Europe are briefly sketched. The fourth section analyzes the road surfacing market before and after the decision. The analysis differentiates between a supply-side analysis, a demand-side analysis, and a market price analysis. Subsequently, the fifth section provides (hypothetical) estimates of the economic effects of the decision. The sixth section concludes the paper and provides avenues for further research.

\section{THE ANTITRUST ECONOMICS OF HARD-CORE CARTELS}

In general, an integrated approach of competition policy against potentially anticompetitive forms of business conduct has to comply with the following steps: A characterization and rationalization of the respective business conduct, an assessment of the welfare effects and the development and implementation of detection and intervention strategies. ${ }^{1}$ The forthcoming sections follow this basic structure with respect to the business conduct hard-core cartel. The discussion is amended by an overview of the general possibilities to assess the effectiveness and the impact of cartel enforcement.

\section{A. Characterization and rationalization of hard-core cartels}

A hard-core cartel is typically defined as “... a group of firms who have agreed explicitly among themselves to coordinate their activities in order to raise market price - that is, they have entered into some form of price fixing agreement." 2 The types of agreement that typically lead to such an increase in market price include not only price fixing agreements in the literal sense but also bid-rigging (collusive tenders), output restrictions and quotas, allocation of customers, suppliers, territories, and lines of commerce. ${ }^{3}$

From a business perspective, firms have an incentive to coordinate their activities, e.g. in the form of hard-core cartels, because this leads to greater profits than acting independently. The basic rationale for this allegation lies in the internalization of a positive externality when firms consider restricting their supply in order to raise prices. In a competitive

\footnotetext{
${ }^{1}$ See Hüschelrath (2009).

${ }^{2}$ Pepall et al. (1999, p. 345).

${ }^{3}$ See Crampton (2003, p. 5).
} 
market, a firm is simply interested in how much a reduction in its own output benefits itself, while it ignores the (positive) effect that a reduction in output has on the profits of the other firms in the market (via the reduction in total market output and the corresponding increase in price). A cartel internalizes this effect by taking into account how changes in the output level of each firm affect joint cartel profits. ${ }^{4}$ As a consequence, it pays for the cartel to reduce total output below the competitive level and thereby increases joint profits.

Although economic research has identified numerous cases in which cartels have aimed at raising joint profits by exploiting customers, empirical studies do not generally support this presumption. In particular, a seminal empirical paper by Asch and Seneca ${ }^{5}$ investigates whether the profit rates of colluding firms differ from those of non-colluding firms and whether the incidence of collusion can itself be explained on the basis of the structure and performance patterns of affected firms and markets. The results of Asch and Seneca show that colluding firms are consistently less profitable than non-colluding firms in the same relevant market, and that important structural differences exist between the two groups. Somehow puzzled by especially the first result, Asch and Seneca nevertheless doubt that collusion really consistently leads to lower profitability and explain their results by the possibility that antitrust prosecution centers largely on the unsuccessful manifestations and leaves the truly successful cartels undetected. ${ }^{6}$

Another explanation discussed by Asch and Seneca ${ }^{7}$ and Rotemberg and Saloner ${ }^{8}$ is the possibility that unsatisfactory performance may motivate firms to collude (under conditions which are not favorable to create stable cartel agreements). Historically, such an argument has been based on the hypothesis that cartels might be 'knights in shining armor', meaning that cartels are formed in difficult economic times characterized by unsatisfactory performance as well as high risk and uncertainty, which is mirrored in cut-throat competition and price warfare. Following Lipczynski and Wilson", "[c]ollusion is seen as a way of easing the pressures of competition by unified action rather than just a strategy to maximize joint profits ... evidence shows that firms enter cartel-type agreements to protect themselves rather than because of a desire to exploit the market. Agreements tend ... to keep out or keep under control potential entrants and new products that could threaten the stability of existing firms." From a historical perspective, Neumann ${ }^{10}$ argues that fundamental changes in production technology in the second half of the nineteenth century led partly via the corresponding changes in the cost structures of firms - to large collaborations which, because of the typically high share of fixed costs, were especially vulnerable in economic downturns. Following Bittlingmayer ${ }^{11}$, especially the combination of high fixed costs facing volatile demand indeed may have caused periods in which the market price dropped below average costs. From that perspective, cartels at that time could be seen as an instrument to fight these price drops and therefore might have been in the public interest. $^{12}$

Although some of these arguments have had played important roles in the toleration of cartels in several European countries in the nineteenth and the early twentieth centuries ${ }^{13}$, contemporary economic research tends not to support the view that cartels nowadays are merely firm reactions to 'tough times'. Apart from general objections against such arguments - which could, for instance, remind of the fact that the pressures of competition play

\footnotetext{
${ }^{4}$ See Carlton and Perloff $(2000,122 \mathrm{ff}$.) for a detailed treatment.

${ }^{5}$ Asch \& Seneca (1975).

${ }^{6}$ See also Shughart \& Tollison $(1998,367 \mathrm{ff}$.$) .$

${ }^{7}$ Asch \& Seneca (1975).

${ }^{8}$ Rotemberg \& Saloner (1986).

${ }^{9}$ Lipczynski \& Wilson $(2001,50 \mathrm{ff}$.).

${ }^{10}$ Neumann $(2000,28$ ff.).

${ }^{11}$ Bittlingmayer (1992).

${ }^{12}$ See Neumann (2000, 28ff.) and Richardson (1965) for more detailed assessments.

${ }^{13}$ See Resch (2005) for an historical overview.
} 
an indispensable role in every market economy (and are typically in the interest of society) - a theoretical assessment by Haltiwanger and Harrington ${ }^{14}$ and empirical studies by Dick $^{15}$ and Bagwell and Staiger ${ }^{16}$ imply that cartels are in danger of breaking apart in recessions. ${ }^{17}$ Such findings are somewhat contradictory to the knight-in-shining-armor motivation to form cartels mentioned above.

In addition to the 'profit-maximization' and 'tough times' arguments, which have been the focus of academic research on the motivation to form cartels, an alternative way to assess this question is to look at the justifications brought forward by detected cartels themselves. Although it is fairly obvious that these arguments do not necessarily have to reflect the true motivations for cartel formation - but might in fact have been developed ex post as part of a defense strategy in court - they nevertheless have to make use of logically sound lines of economic reasoning. In a detailed assessment of these justifications for cartels, the World Bank ${ }^{18}$ identifies four frequently applied arguments: the industry cannot function with competition; the industry competes on service and quality; safety and quality will decline without the cartel; and the cartel is necessary to stop unfair and unethical competition. These arguments all have in common that they are built on the belief that competition is not working in the industry (from the perspective of the cartel firms), and therefore that a concerted action by the industry - which might lead to elevated prices, but which also produces benefits for the consumers (by maintaining a high level of service and quality as well as safety) - is justified. Without wanting to enter into a detailed economic assessment of these 'excuses' for cartel formation ${ }^{19}$, one simple but disarming counterargument would be that it is not the industry that has to decide whether competition is unworkable. Economic research and practical experiences in the majority of cases show that competition is typically socially desirable and it is up to the respective state bodies to decide whether some form of regulatory intervention is necessary, for example, to secure a high level of safety or to water down the consequences of unethical competition.

\section{B. Welfare effects of hard-core cartels and competition policy implications}

Given the assessment of the business motivations for hard-core cartels in the last section, an assessment of the welfare effects seems to be straightforward. A perfectly functioning hard-core cartel (involving all firms in the market) leads to the same market outcome as a monopoly and therefore causes similar types and degrees of allocative, productive and dynamic inefficiencies. Additionally, hard-core cartels usually do not create any kind of benefits to society which could be traded-off against the anticompetitive effects from an antitrust perspective. As a consequence, contemporary hard-core cartels are a prime candidate for a per se prohibition irrespective of the particular characteristics of the industry, product or type of agreement.

Despite this clear statement with respect to the welfare effects of hard-core cartels, simple game-theoretic reasoning suggests that antitrust bans (and antitrust enforcement) against such cartels may be unnecessary, because firms will typically fail to stabilize cartel agreements and, hence, the negative welfare consequences predicted above would not materialize. In a simple one-shot duopoly game, for example, it is straightforward to show that competition and not cartelization is the dominant strategy for both firms. Although both firms realize that they would achieve a higher profit in the cartelization state, they also realize that the rival firm has a substantial profit incentive to cheat on such a collusive agreement. As both firms anticipate this possibility (as well as the negative consequences

\footnotetext{
${ }^{14}$ Haltiwanger \& Harrington (1991).

${ }^{15}$ Dick (1996).

${ }^{16}$ Bagwell \& Staiger (1997).

${ }^{17}$ See Neumann $(2000,31 \mathrm{f}$.).

${ }^{18}$ World Bank (1999, 24ff.).

${ }^{19}$ See World Bank (1999, 24f.).
} 
for their own profit), it is the dominant strategy for both firms not to collude. The subsequent policy conclusion would be that, although cartel agreements in theory harm social welfare, it is not necessary to consider antitrust bans or even antitrust actions against them, as firms typically fail to stabilize such agreements anyway.

The diagnosed chronic instability of cartels in one-shot games is basically caused by a lack of trust between the two companies. Although it is admittedly hard to establish trust in one-shot games, it is also hard to believe that one-shot games are a suitable description of real markets. Typically, firms meet regularly in a market (or even in a couple of markets) and this repeated interaction creates possibilities to stabilize cartel agreements. Although it cannot be the aim of this section to give a comprehensive overview of possible strategies to stabilize cartels ${ }^{20}$, it is straightforward to see that repeated interaction gives cartel members the opportunity to implement effective punishment strategies for cheaters which also reduce the incentives to deviate and therefore stabilize the cartel. ${ }^{21}$

Although firms have developed various incentive schemes to stabilize cartel agreements, these schemes typically cannot be applied profitably in every market environment. The underlying economic reasons are twofold. On the one hand, the profit differential between the cartel profit and the competitive profit - i.e., "the difference between the most profitable outcome possible for the firms (the best possible Nash equilibrium) and the worst" 22 - depends on the specifics of the market and market interaction. On the other hand, the costs of operating a cartel - i.e., reaching and monitoring cartel agreements, and possible antitrust fines and damages - also depend on the specifics of the market and market interaction and might become prohibitive in certain constellations. To give a simple example, consider a market with 10 firms and a market with 3 firms. Ceteris paribus, it can be expected that it is more costly to reach and maintain a cartel agreement in a market with 10 firms than in a market with only 3 firms, simply because negotiations (and the subsequent monitoring) among 10 parties is typically more complex and expensive than negotiations among only 3 parties.

In addition to this simple structural example focusing on the number of firms in a market, theoretical research has identified an ample number of additional factors which have the potential to influence the potential benefits and costs - and therefore the rationality and stability - of cartels and collusion. Rey ${ }^{23}$ - in accordance with many other commentators on the topic - subdivides these factors into structural, supply-related and demand-related factors. Structural factors that ease collusion include a low number of competitors (as discussed above), high entry barriers, frequent interaction between firms, and market transparency. Demand-related factors include market growth, absence of significant fluctuations or business cycles, low demand elasticity, buying power, and the absence of club and network effects. Finally, supply-related factors which ease collusive agreements include mature industries (with stable technologies), symmetric costs, symmetric capacities, product homogeneity, multi-market contact, structural links and collaborations, and other contractual agreements. The theoretical reasoning upon which these different collusion factors are based can be found, for instance, in $\operatorname{Rey}^{24}$, Motta ${ }^{25}$, Ivaldi et al. ${ }^{26}$ and Grout and Sonderegger. $^{27}$

\footnotetext{
${ }^{20}$ See, e.g., Schulz (2003) and Feuerstein (2005) for surveys.

${ }^{21}$ Imagine a simple duopoly game that is played infinitely. It is then possible to show that the incentive to cheat depends on the discount factor $\delta$. In other words, as long as the discount factor is sufficiently high (i.e., the firms are sufficiently patient and value future profits to a sufficient extent), deviation does not pay for either of the firms and the agreement is therefore stable.

${ }^{22}$ Whinston (2006, p. 40).

${ }^{23}$ Rey (2006).

${ }^{24}$ Rey (2006).

${ }^{25}$ Motta (2004).

${ }^{26}$ Ivaldi et al. (2003).

${ }^{27}$ Grout \& Sonderegger (2005).
} 
In addition to theoretical research, empirical studies have shown that firms can not only be successful in maintaining their agreements over long time periods but often also manage to overcome cartel crises, such as market entry of new firms or the emergence of dispute among existing cartel members. ${ }^{28}$ Although cartels typically fail to reach the outcomes of a hypothetical single monopolist - given the existence of cartel outsiders or remaining forms of non-price competition (which keep up some competition) - they often manage to raise prices significantly above competitive levels. Audretsch ${ }^{29}$, for instance, found significantly elevated market prices for a sample of cartels in Western Germany. Connor and Lande ${ }^{30}$ collected average overcharges of six economic surveys consisting of more than 100 cartels. They find that the average cartel overcharges differ considerably among the different empirical studies. Levenstein and Suslow ${ }^{31}$, for instance, calculate an average overcharge (mean) of $43 \%$, while Werden ${ }^{32}$ finds $21 \%$ and the $\mathrm{OECD}^{33} 15,75 \%$ for the average overcharge (mean). The average of all studies shows a mean of 30,7\%. Typically, the deadweight losses caused by cartels add between $10 \%$ and $30 \%$ of the overcharges in order to receive the total customer losses due to cartelization.

Following the theoretical and empirical evidence it can be concluded that hard-core cartels are a prime candidate for a per se prohibition. ${ }^{34}$ Such a conclusion does not necessarily preclude the possibility that there might occasionally be hard-core cartels which would have raised overall welfare; however, such occurrences are considered so rare that a per se ban remains the appropriate antitrust reaction. ${ }^{35}$ Assuming that such a per se ban of hardcore cartels is codified, the questions occur how an competition authority (together with the complementary court system) can reduce the formation of cartels and how it can detect and punish existing cartels. With respect to the first question, the competition authority can apply certain ex ante instruments (such as blacklists, regulation of communication or coordinated effects analysis in merger control) which aim at preventing the formation of cartels in the first place. With respect to the second question, the competition authority can revert to several ex post instruments (such as leniency programs or active market monitoring) which focus on detecting cartels in the literal sense. ${ }^{36}$ The subsequent interventions against detected hard-core cartels are motivated by the belief that the imposition of fines discourages attempts by firms to form hard-core cartels. Consequently, the fundamental purpose of antitrust fines is to create and keep up an (ex ante) deterrence effect by signaling to the companies that substantial fines will have to be paid if their conspiracy is detected.

\section{Assessing the effectiveness and the impact of cartel enforcement}

In general, an assessment of the effectiveness and the impact of cartel enforcement face an identification problem. If only a few cartels are detected, this could on the one hand be an indicator of a successful deterrence policy of the competition authority. On the other hand, however, an alternative interpretation of such an observation could be that the competition authority follows an ill-equipped approach to detect cartels or suffers from insufficient resources to exercise its duties conscientiously. Vice versa, an increase in the detection of cartels could on the one hand be an indicator that certain policy changes were steps in the right direction. However, on the other hand, it could also indicate that only the number of

\footnotetext{
${ }^{28}$ See Levenstein \& Suslow (2004) for a comprehensive overview.

${ }^{29}$ Audretsch (1989).

${ }^{30}$ Connor \& Lande (2006).

${ }^{31}$ Levenstein \& Suslow (2004).

${ }^{32}$ Werden (2003).

${ }^{33}$ OECD (2003).

${ }^{34}$ It should be noted at this point that only price agreements involving substitutes are considered here as hardcore cartels. The welfare implications of price agreements affecting subsequent production stages (i.e. complementary products) are far less clear from an academic as well as practical perspective.

${ }^{35}$ See also Whinston (2006, $15 \mathrm{ff}$.).

${ }^{36}$ See Motta (2004, 190ff.).
} 
cartels has risen and the competetion authority was able to detect some of them more or less accidentally. As a consequence, the number of detected or prosecuted cartels is typically an inappropriate indicator for the effectiveness of a cartel enforcement strategy of a competition authority.

Despite the crucial identification problems, economists nevertheless have identified several possibilities to assess the effectiveness and the impact of cartel enforcement. Generally, the existing studies can be subdivided into two parts: macro studies which assess the effectiveness of a cartel enforcement strategy of a competition authority and micro studies which investigate the precise impact of particular cartel enforcement actions. For conducting macro studies, it is first necessary to derive a best practice framework. If serious deviations from this best practice framework are found it can be assumed that the competition policy actions with respect to cartels are suboptimal. A straightforward example of such a study would be an assessment of the leniency program of a competition authority. Another focus which recently attracted significant attention is the question whether the fines actually collected by the competition authorities come anywhere near to the theoretically derived optimal fines (and therefore signal firms that cartelization does not pay). Veljanovski ${ }^{37}$, for instance, collected data on duration, fines imposed, sales, overcharges and consumer losses for several detected and prosecuted hard-core cartels in the European Union. He further calculated the theoretically optimal fines - largely based on the respective cartel overcharge estimate (the measure for 'harm caused') as well as a presumed probability of detection for cartels of 33\%. He finds that the fines collected by the European Commission largely under-deter price-fixing. The optimal fine would have been between 1.6 and 115.5 times higher than the fines actually imposed. However, although these results on the surface speak for significant under-deterrence, it has to be kept in mind that the public fines considered by Veljanovski might be complemented by other costs, which can be interpreted as additional fines from the viewpoint of the cartel members. In addition to negative stock price reactions and private damage claims, whose importance recently began to grow in the European Union, an additional cost is created by the lawsuit itself (and the respective fees for lawyers and economists) ${ }^{38}$. Furthermore, as found by Karpoff et al. ${ }^{39}$, the reputation effect typically causes the major loss subsequent to discovery of suspicious behavior. These losses are found to be particularly high if the violation was to the detriment of customers.

The micro studies investigate the precise impact of particular cartel enforcement actions. For example, one possibility is to focus on an analysis of customer losses due to actual cartelization and to argue that without successful cartel enforcement the respective cartels would have continued to exist, causing welfare losses. In other words, the direct benefits of detecting a cartel can be approximated by the net present value of the yearly benefits for society in the future ${ }^{40}$. However, it is obvious that such an analysis can only measure a fraction of the real welfare contribution of cartel enforcement as the benefits achieved through deterrence are excluded from the analysis.

Still aiming at assessing the impact of hard-core cartel enforcement on a micro level, another quantitative possibility is to analyze its effect on post-cartel prices. From a theoretical perspective, the breakdown of a cartel should be followed by price declines down to the non-collusive level. Empirical evidence, however, partly suggests that this price decline is often less significant. Feinberg ${ }^{41}$, for example, found a decline in average prices in four out of five investigated cartels between $6.6 \%$ and $11.4 \%$ which, however, partly disap-

\footnotetext{
${ }^{37}$ Veljanovski (2007).

${ }^{38}$ See, e.g., OECD (2007, p. 30).

${ }^{39}$ Karpoff et al. (2008).

${ }^{40}$ See Hüschelrath (2009) for a case study.

${ }^{41}$ Feinberg (1984).
} 
peared in the five years following the cartel detection. Sproul ${ }^{42}$ surveys 25 price-fixing cases between 1973 and 1984 with respect to the price levels four years after the breakdown. He finds an increase in prices of $7 \%$ on average for his sample. Thompson and Kaserman $^{43}$ analyze the stock price movements 'after the fall' of 57 price-fixing cases with 127 firms involved. They find that within roughly one year of indictment, the stock prices of $85 \%$ of the firms in the sample had returned to their pre-indictment (collusive) values. Confronted with these results, they conclude that cartel enforcement has a very little lasting effect on market outcomes. "While it punishes individual offenders, it does not effectively deter collusion on any sort of sustained basis" ${ }^{44}$, basically because the cartel-adequate market structures remain unchanged after the conviction (and so the general incentives to re-build the cartel at a later point). In line with this finding, Harrington ${ }^{45}$ concludes from his review of the empirical research that cartel enforcement typically leads to price declines in the short run, however, that price increases are often experienced in the medium and long run. One explanation for this observation could be that firms learned to collude tacitly and therefore managed to realize prices above the competitive level. In addition to the fact that the detection of a cartel does not change the collusion-friendly market structure of the industry (and therefore keep up the basic collusion incentives), the cartel members might have an additional incentive to avoid fierce price competition in the post-cartel period, as this would signal the court a higher harm caused by the cartel (probably causing the fixation of a lower 'but-for' price in the trials).

Despite this somewhat mixed empirical evidence on the impact of cartel enforcement, it is important to recall the significance of the deterrence effect of sanctioning cartels. Block et al. ${ }^{46}$, for example, test their theoretical model described above and indeed find for the US bread industry that an increase in the DOJ's enforcement capacity or filing of a DOJ price-fixing complaint had a negative effect on the price markups. Furthermore, Block and Feinstein ${ }^{47}$ find evidence on the existence of a deterrence effect in highway construction procurement auctions. Clarke and Evenett ${ }^{48}$ show for the case of the international vitamins cartel that the cartel reduced its overcharges in jurisdictions with tough cartel enforcement. For most European jurisdictions, this reduction in overcharges reached by the presence of tough cartel enforcement regimes was already large enough to cover a substantial proportion of the overall budgets of the respective competition authorities (including the budget of DG Competition at the European Commission). Finally, Symeonidis ${ }^{49}$ analyzes the effect of the introduction of anti-cartel laws in the United Kingdom in 1956 and finds that price competition increased and led to lower margins in industries which had been previously cartelized.

Based on these existing studies on the effectiveness and the impact of cartel enforcement it is the aim of the remainder of the paper to analyze the impact of the detection of a hard-core cartel in the Swiss market for road surfacing on post-cartel competition. In addition to an investigation of supply-side factors, demand-side factors and market prices, the paper also derives estimates of the economic effects of the decision.

\section{THE SWISS ROAD SURFACING CARTEL CASE AT A GLANCE}

Following Article 5 of the Swiss Cartel Act (KG), [a]greements that significantly affect competition in the market for certain goods or services and are not justified on grounds of

\footnotetext{
42 Sproul (1993).

43 Thompson \& Kaserman (2001).

${ }^{44}$ Thompson \& Kaserman (2001, p. 334)

${ }^{45}$ Harrington (2005, p. 5).

${ }^{46}$ Block et al. (1981)

${ }^{47}$ Block \& Feinstein (1986).

${ }^{48}$ Clarke \& Evenett (2003, 725f.).

${ }^{49}$ Symeonidis (2000).
} 
economic efficiency and all agreements that lead to the suppression of effective competition are unlawful.' Under the old Swiss cartel law (effective before April 2004) only companies which repeatedly offended this cartel ban were subject to pecuniary fines. With the commencement of the amendment of the Swiss Cartel Act on 1 April 2004, the Competition Commission (COMCO) gained considerably new powers, especially with respect to the possibilities to sanction anticompetitive behavior by imposing substantial fines already for first offenders.

In the following sections the Swiss road surfacing cartel case is sketched with respect to the decision as well as the economically meaningful relationships of the inquiry of the Competition Commission. The entire inquiry and the decision is published in German language in the 4/2004 edition of Recht und Politik des Wettbewerbs ${ }^{50}$ which is the official journal of the Swiss Competition Authorities.

\section{A. The case over time}

On 3 November 1998, legal representatives of two road construction companies in Northeastern Switzerland - Kiesel Girsberger and Buettner - filed charges at the COMCO for an alleged cartel agreement in the market for road surfacing in Northeastern Switzerland (including the neighboring foreign countries Germany and Austria).

In the aftermath, the office of the COMCO carried out preliminary investigations between 21 December 1998 and 20 July 1999 which resulted in several indications that a number of vertically-integrated road surfacing companies in the region agreed upon prices, quantities and locations in the market for asphalt mix which is an essential input good for road surfacing. It was assumed that a so-called exclusive dealing agreement (EDA) was introduced aiming at separating the high-price country Switzerland from its lower-price neighboring countries. As a consequence, competition in the downstream markets of road surfacing and road construction in Northeastern Switzerland was distorted.

Given the indications of an existing cartel agreement, the office of the COMCO started an enquiry of the market for road surfacing on 20 July 1999. The initial focus of the enquiry was a couple of holding companies active in Northeastern Switzerland - namely BHT, BHZ, Biturit, FBB and Siderit. However, in the course of the enquiry, evidence was found that other companies with a direct or indirect share in the holding companies Siderit, BHZ, BHT and Biturit, could also have participated in the cartel. As a consequence, the enquiry was extended to include all road construction companies listed in Figure 1 below.

\footnotetext{
${ }^{50}$ The journal can be accessed at http://www.weko.admin.ch/dokumentation/00157/index.html?lang=de .
} 


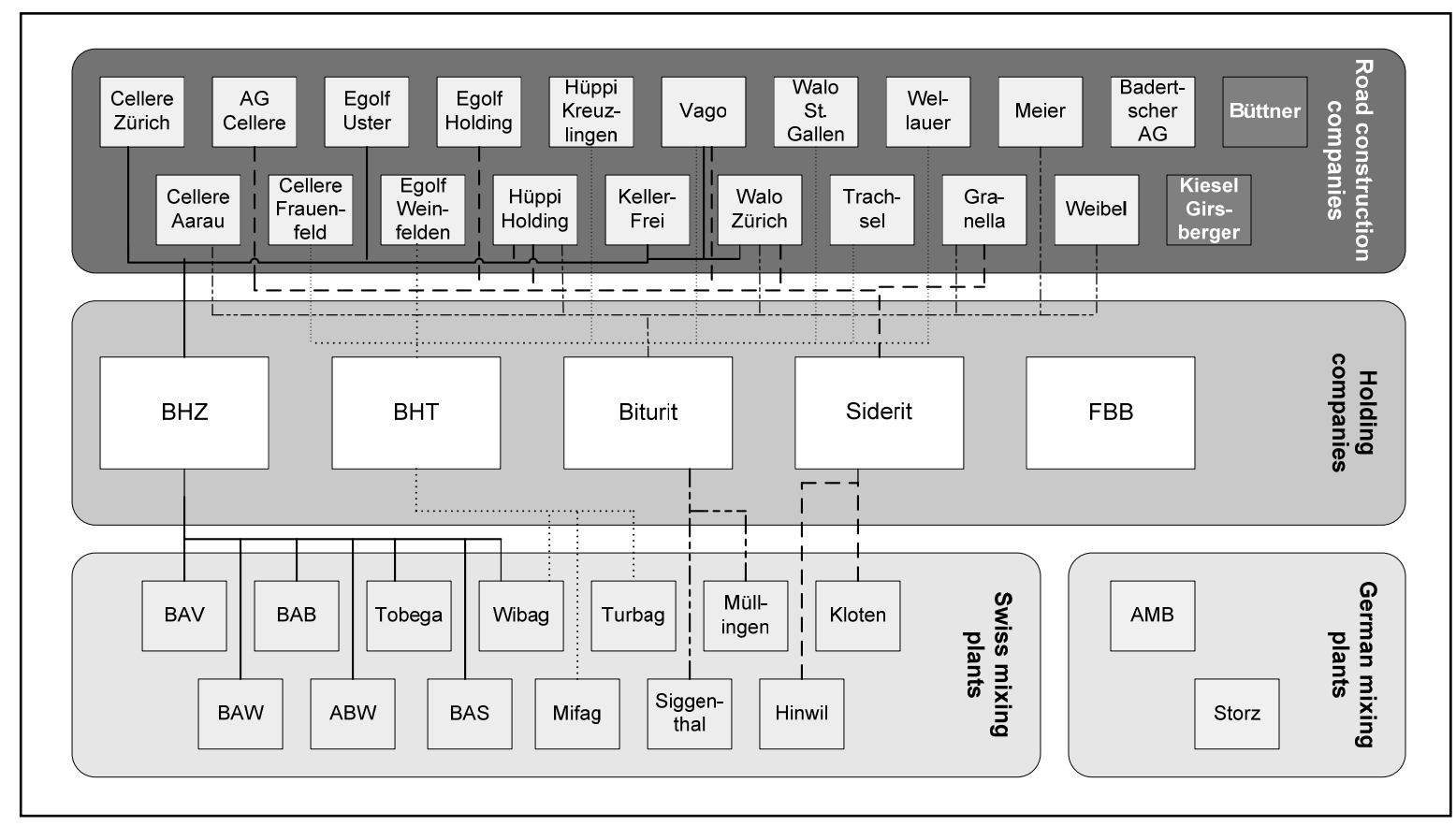

Figure 1. The industry structure at the time of the investigation.

As shown in Figure 1, the industry structure at the time of the investigation is characterized by a number of road construction companies that hold shares in a couple of holding companies. These holding companies are the legal owners of the mixing plants for asphalt mix in Northeastern Switzerland.

On 4 December 2000 the Competition Commission decided on the case. The exclusive dealing agreement (EDA) was classified as an illegal type of collusion and its termination was commanded.

\section{B. The enquiry}

The exclusive dealing agreement (EDA) primarily affects the cantons of Schaffhausen, Thurgau and Zurich in Northeastern Switzerland. However, given their proximity to the Swiss border, the neighboring German companies, AMB and Storz, were also included in the EDA. This is especially relevant because the prices for asphalt mix in Germany were significantly lower than in Switzerland, leaving the German companies with a possibly significant cost advantage.

\section{Exclusive dealing agreement (EDA)}

On 24 June 1996 Siderit and AMB reached a written agreement that AMB would guarantee Siderit exclusive distribution rights for Hot Mix Asphalt for the cantons of Aargau, Zurich, Schaffhausen and Thurgau. In turn, Siderit agreed to sell a minimum of 20,00030,000 tons per year of AMB's production in Switzerland. Moreover, Siderit obligated itself to stop the delivery of asphalt mix to Germany. The key aim of the agreement was to raise the market prices in Switzerland in such a way that Siderit could successfully survive in the Swiss market. The coordination of the contract was taken over by BHZ.

On 29 May 1997, Badertscher AG signed a contract with Siderit, BHZ, BHT and Biturit with the following content: Siderit and Badertscher AG fix the prices for the quantities of asphalt mix imported from Germany into the cantons of Thurgau and Zurich. Badertscher AG would, on behalf of BHT, carry out the allocation of the German asphalt mix in the canton of Thurgau. The transportation costs for the delivery of the German asphalt mix would be borne by Siderit. Furthermore, Badertscher AG agreed not to procure or process asphalt mixes from competing plants either within Switzerland or from abroad. 


\section{The relevant market for an assessment of the EDA}

With respect to the delineation of the product market, the typical customers of road construction companies are the respective state departments responsible for road construction. The choice of the mixing plant which delivers the asphalt mix, however, falls under the authority of the construction company who is consigned with the respective construction project. Typically, the construction of asphalt roads takes place by applying three layers of asphalt - the wearing layer, the base layer, and the foundation layer. The asphalt mix needed for these layers has slightly different configurations, however, mixing plants are usually suited to produce asphalt mixes for all three layers so that the layer material for a construction site is usually delivered from a single mixing plant. As a consequence, the relevant market is found to be the whole market for 'road surfacing', in which mixing plants compete against each other.

With respect to the geographical dimension of market delineation, the intensity of competition for a certain road surfacing project is dependent on the geographical location of the construction site. In particular, two factors play an important role: First, the transport cost restrictions and second, the quality state of the asphalt mix when reaching the construction site. Both factors are determined by the transport duration. With respect to the first, transportation costs typically increase with the transported distance. As a consequence, even if a certain mixing plant has a cost advantage in the production of asphalt mix, this advantage diminishes with increased distance to the construction site. With respect to the second factor, asphalt mix quality, transport duration is also a crucial determinant for the intensity of competition as the asphalt mix cannot be processed at the construction site if its temperature falls below a certain threshold value. As a consequence, the market for asphalt mixes is in fact a collection of regional markets which continuously change due to variations of the construction sites. As a point of reference, the office of the COMCO estimated that mixing plants can procure asphalt mix in an acceptable quality within a driving distance of approx. $60 \mathrm{~min}$. This corresponds to a geographical radius of about $50-80 \mathrm{~km}$.

Given the geographical market delineation and especially the estimated maximum driving distance of $60 \mathrm{~min}$ as the radius around the respective mixing plants of AMB and Storz, the regions directly affected by the EDA can be identified. This impact area is named W1 in Figure 2 below.

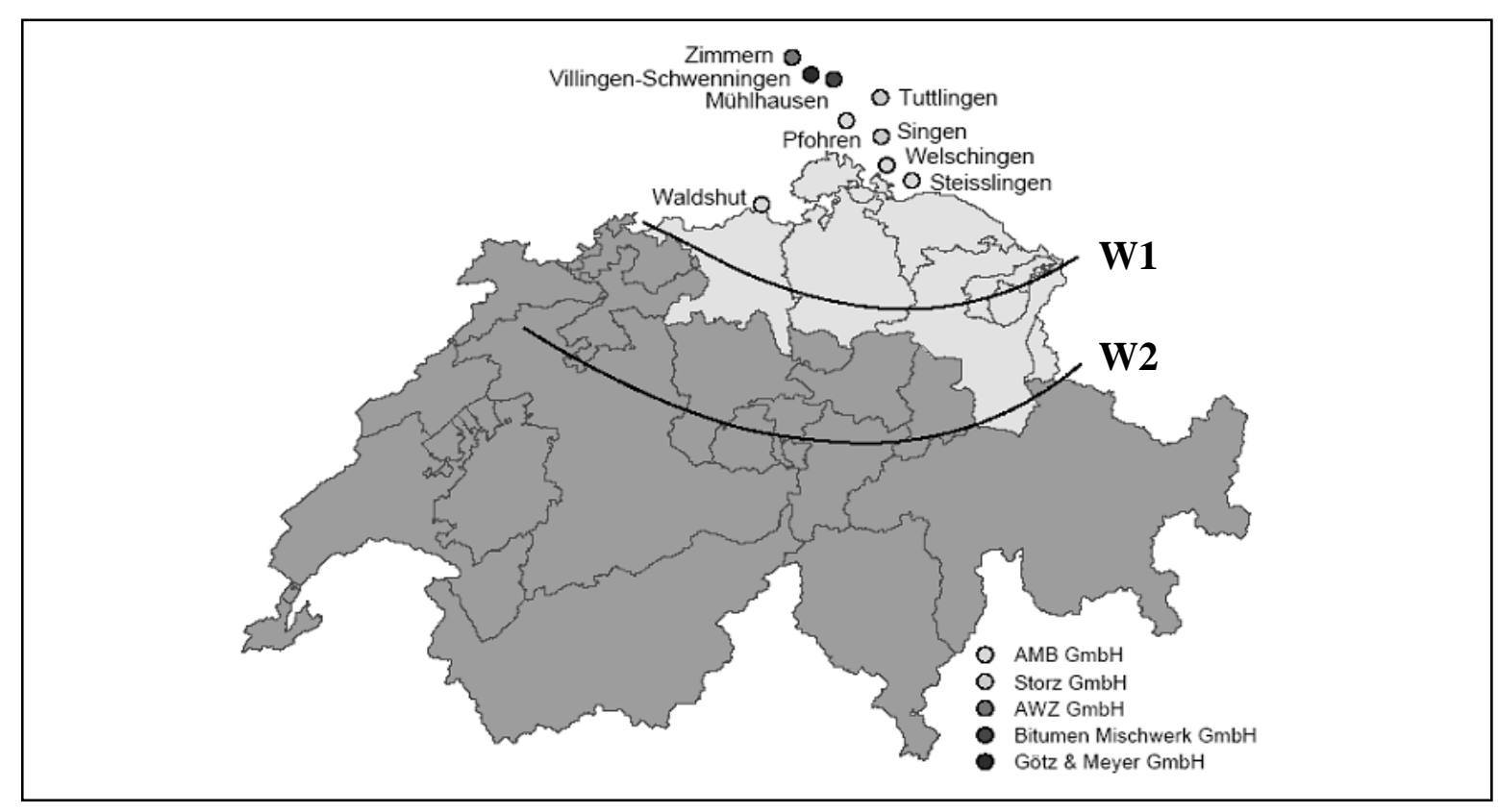

Figure 2. Impact areas of the German mixing plants (W1) and the agreement (W2). 
A dot in Figure 2 represents a German mixing plant which can theoretically deliver asphalt mix into Switzerland and therefore possibly imposes some kind of competitive constraint (which was tackled by the EDA). Again assuming the 60 min radius, Figure 2 also allows delineating an impact area of the agreement within Switzerland. This area is named W2 in Figure 2 and involves the possible distribution areas of all companies which were involved in the EDA. As a consequence, the COMCO delineated the relevant market for the assessment of the EDA as impact area W2.

\section{The impact of the EDA on competition}

Given the delineation of impact areas determined by the locations of the mixing plants it is straightforward to deduce a clear picture of how road surfacing companies or mixing plant owners, respectively, compete against each other. Given the location of a certain construction site, road construction companies generally have the choice between all mixing plants whose production site is with the 60 min radius. ${ }^{51}$ Under the assumption that no geographical price differentiation is possible, economic theory would expect that the competitive pressures of the intersecting areas (i.e. construction sites which are located in the distribution areas of at least two (independent) mixing plants) are carried forward to those areas in which delivery is only possible from one mixing plant. As a consequence, ideally, the producers of asphalt mix in W1 are in direct competition with the German plants of AMB and Storz. Absent of possibilities to price discriminate, this competitive pressure is carried forward to W2. The aim of the EDA was to reduce or even eliminate this effective competition.

Focusing in a more detailed way on an assessment of the competitive pressure within Switzerland, the office of the COMCO found that the prices for asphalt mix of AMB and Storz before the EDA agreement were roughly 50\% lower than the average price charged by Swiss producers. As explained above, this imposed significant competitive pressure on Swiss companies located in the centre of $\mathrm{W} 1$. The independent road construction companies profited from this as they received their asphalt mix at least partly from German mixing plants. Following the introduction of the EDA, these independent companies weren't able to receive asphalt mix from German plants any more. Additionally faced with a pricing policy by the vertically-integrated Swiss construction companies that strongly favored the shareholders ${ }^{52}$, the independent firms weren't able to compete against the vertically integrated companies any more. Since the share of costs for mixing materials is estimated as $15-60 \%$ of total costs for road construction, the EDA had significant impact on competition between the German and Swiss plants. Following the introduction of the EDA on 1 July 1996 and its extension on 4 August 1997, the direct procurement of asphalt mix from the German plants of AMB and Storz was not possible anymore. As a consequence, the prices charged by the German mixing plants increased from 1996 to 1998 by about $40 \%$. In the same period the prices of the participating Swiss companies increased by less than 5\%

\footnotetext{
${ }^{51}$ As already identified above, transport costs play a crucial role in assessing the competitive pressures within the industry. If the ex-factory prices of two mixing plants are equal, the construction company will source from the mixing plant which is closest to the construction site as this would minimize the sum of production and transportation costs. As a consequence, the plant with a geographical proximity advantage has some price setting flexibility. Generally, the competitive pressures created by other mixing plants diminish with increasing transport distances.

${ }^{52}$ The suppliers of asphalt mix price discriminate with respect to customer segments. The following segments existed: Shareholders, independent road construction companies, bulk and small buyers. The investigation of the COMCO found that, first, the price differences of BHT, BHZ and FBB did not vary over the years or for the different types of asphalt mix. Second, the average price differences between the customer segments are relatively high for all companies. These price differences weaken the competitive position of the independent road construction companies such as Kiesel Girsberger and Buettner who have to pay significantly higher prices for their asphalt mix than the companies belonging to the EDA.
} 
(already taking account of an average inflation rate of 3\%). This observation clearly indicates that the competitive pressure which originally came from the German plants was reduced or even eliminated by the EDA allowing the participating Swiss plants to maintain an excessive price level and inefficient production structures. This assumption was underpinned by the fact that nearly all vertically-integrated companies in the cantons of Zurich, Thurgau and Schaffhausen participated in the EDA leaving no room for competition to survive. As a consequence, it can be assumed that there was no effective outside competition from independent companies which could weaken or even eliminate the harmful competitive effects of the EDA. Additionally, the analysis of the office shows that the probability of market entry (as another factor which might constrain the harmful competitive effects of the EDA) is low. The same low probability applies for a possible disciplining effect of the opposing market side, the construction companies.

\section{Conclusion}

Based on the analysis just sketched, the office of the COMCO concluded that the EDA significantly reduced or even eliminated effective competition in the market for road surfacing in Northeastern Switzerland. The EDA was therefore classified as a form of illegal collusion following Article 5 (Paragraph 1) KG. By terminating the EDA, it can be expected that asphalt mix could be delivered at considerably lower prices from German plants creating competitive pressures on the Swiss mixing plants and thereby restoring effective competition in the market.

\section{Related cases in Europe}

In addition to the road surfacing cartel case just described, Switzerland and other European countries have seen a couple of similar cartel cases. In the following, several recent examples are sketched. The observation that collusive agreements are by no means an exception in this market is a clear sign that it is both possible and profitable to enter into some form of cartel agreement. Industrial economists have identified an ample number of factors (relating to market structure and market behavior) which might facilitate collusion (see section II.B. above for a brief overview). At least some of these criteria, such as product homogeneity, high market entry barriers, existing ownership links or multi-market contact are present in the market for road surfacing.

\section{Road surfacing cartel in the Swiss canton of Ticino (2007)}

In April 2005 the COMCO opened an enquiry in the market for road surfacing in the Swiss canton of Ticino. The enquiry was launched following a complaint from Ticino's Dipartimento del Territorio which presented evidence that firms were coordinating tenders for road maintenance work by geographical area and on a rotational basis. In its decision of 19 November 2007 the COMCO concluded that the firm's agreement fulfils all criteria of a hard-core cartel and thus is a serious infringement of the Swiss Cartel Act. The agreement caused considerable damage to private clients, public authorities and the taxpayer. The enquiry found that the agreement between 17 of the 18 road construction companies active in Ticino was effective from January 1999 to (at least) the end of 2004. The key aim was to guarantee the respective cartel members certain market shares which were agreed in advance by controlling the allocation of public and private contracts. The firms met weekly to award contracts and decide on compensations. As the cartel agreement was ended before the deadline which ends the transition period from the old to the new cartel law (31 March 2005), the firms cannot be punished (as they were all first offenders). If such a cartel would be detected under the revised cartel law, the amount of fines for the companies would have been around CHF 30 million. 


\section{Asphalt mixing plant in Austria (2006)}

On 15 March 1999 four construction companies in Austria founded a joint venture to build a new asphalt mixing plant, each of them holding a share of $25 \%$. Simultaneously, they planned to close down two older mixing plants. After the compulsory notification, the Austrian Competition Authority banned the joint venture as it would likely monopolize the market for asphalt mix in the respective region of Austria. The agreement would constitute an effective cartel particularly because the members agreed not to build additional asphalt mixing plants in proximity to the joint venture plant.

The detailed enquiry of the Competition Authority started in 2004. The court carried out extensive preliminary investigations with a couple of key conclusions. The companies involved in the joint venture were among the four largest road construction firms in Austria at the time with a combined market share of around $80 \%$ of the country's road construction market. In the area served by the joint plant the owners also completely or partially owned a number of other mixing plants. The jointly-operated plant provided around $10 \%$ of asphalt mixture needed in the regional market. The companies themselves held a share of $75 \%$ of the regional market for asphalt mixture and $70 \%$ of the Austrian market. Top managers of the four companies met on several occasions and discussed the purchase prices paid by the parent companies for intermediate products needed at the plant. Despite excess capacity and measures to rationalize production, the price of asphalt mix increased continuously until 2002. All of the road construction firms involved continued to sell asphalt mix to their customers at almost exactly the same price until 2004.

The Austrian Court of First Instance looked at the case and decided that the firms' activities constituted a cartel agreement rather than a merger or joint venture, especially because the firms involved in the joint venture had entered a commitment to avoid the construction of any additional mixture plant in the region. The court ordered the immediate termination of the cartel. The decision on a possible fine was suspended.

\section{Bitumen cartel in the Netherlands (2006)}

Between 1994 and at least 2002 delegations from eight suppliers of road bitumen (BP, Esha, Klöckner Bitumen, Kuwait Petroleum, Nynäs, Shell, Total and Wintershall) and six construction companies (Ballast Nedam, Dura Vermeer, Heijmans, Hollandsche Beton Groep, Koninklijke BAM Groep and Koninklijke Volker Wessels Stevin) met on several occasions in the Netherlands in so-called 'bitumen consultations'. The consultations were generally preceded by separate preparatory meetings between the suppliers and the country's six largest road construction firms. During the meetings, the gross price of all road bitumen sold to asphalt manufacturers in the Netherlands was fixed. In addition, uniform minimum rebates were agreed for construction companies that belonged to the cartel, along with lower maximum rebates that could be granted to constructors outside of the cartel. The construction companies involved in the cartel were apparently less concerned about the actual price of bitumen than about securing larger discounts than their smaller competitors. As a result, the price of bitumen in the Netherlands gradually rose above that in neighboring countries, even taking the discounts offered to the larger road constructors into account. As such, all of the companies involved, be they suppliers or purchasers, profited from the cartel. The European Commission worked on the assumption that a price cartel was in existence, in clear contravention of Article 81 of the EC Treaty. The firms involved were fined a total of EUR 266,717 million.

\section{Asphalt Cartel in Finland (2007)}

On 19 December 2007 Finnish Competition Court imposed fines totaling EUR 19.4 million on firms that had been part of the Finnish Asphalt Cartel. The Court's decision confirmed the Finnish Competition Authority's conclusions that the firms in question, which controlled a combined market share of over $70 \%$ of the Finnish market, were found guilty 
of fixing prices and coordinated bidding. This was found to have affected central government construction projects between 1996 and 2000, as well as local government and private projects from 1994 to 2001.

\section{Asphalt Cartel in Sweden (2007)}

On 10 June 2007 the Stockholm District Court imposed fines of EUR 53 million on nine companies that had participated in the Swedish Asphalt Cartel. In doing so, the court confirmed the analysis and conclusions of the Swedish competition authority. The court considered the proof to be sufficient that the firms involved had allocated market shares among themselves over a number of years by reaching agreements on bidding. In addition, evidence was found that larger road construction firms had paid smaller companies not to submit tenders. The asphalt cartel is the largest cartel ever that has been uncovered and punished in Sweden.

\section{IV.THE ROAD SURFACING MARKET BEFORE AND AFTER THE DECISION}

The key aim of the case study lies in the identification of the economic effects of the detection of the cartel by the Swiss Competition Commission. In order to reach this aim, the Swiss market for road surfacing needs to be analyzed from the supply side (Section IV.A.), the demand side (Section IV.B.) and with respect to the development of the market prices (Section IV.C.). The availability of longer time series partly allows a comparison of indicators before, during and after the cartel agreement.

\section{A. Supply-side analysis}

The analysis of the supply-side of the market for road surfacing in Switzerland is twostaged. First, the Swiss market is compared to other European road surfacing markets. Such an analysis may help to identify untypical developments in Switzerland. Second, the international trade flows of Hot Mix asphalt involving Switzerland and Germany need to be investigated. Such an analysis may help to identify changes due to the termination of the cartel agreement.

\section{The Swiss road surfacing market - An international comparison}

With the aim of characterizing the key developments on the supply-side of the market for road surfacing in Switzerland, several main market structure parameters needs to be investigated such as market size (production output), the number and structure of production plants or the degree of the vertical integration. In order to interpret the structural characteristics over time, it seems straightforward not only to present the respective time series for Switzerland, but to compare this data with the data for other European countries.

For an initial description of the supply side of the market for road surfacing, an analysis of the time series of the production of ,Hot Mix Asphalt' is helpful to get an idea whether the market is growing, stagnating or shrinking. Figure 3 shows the production of Hot Mix Asphalt from 1996 to 2005 in smaller European countries. 


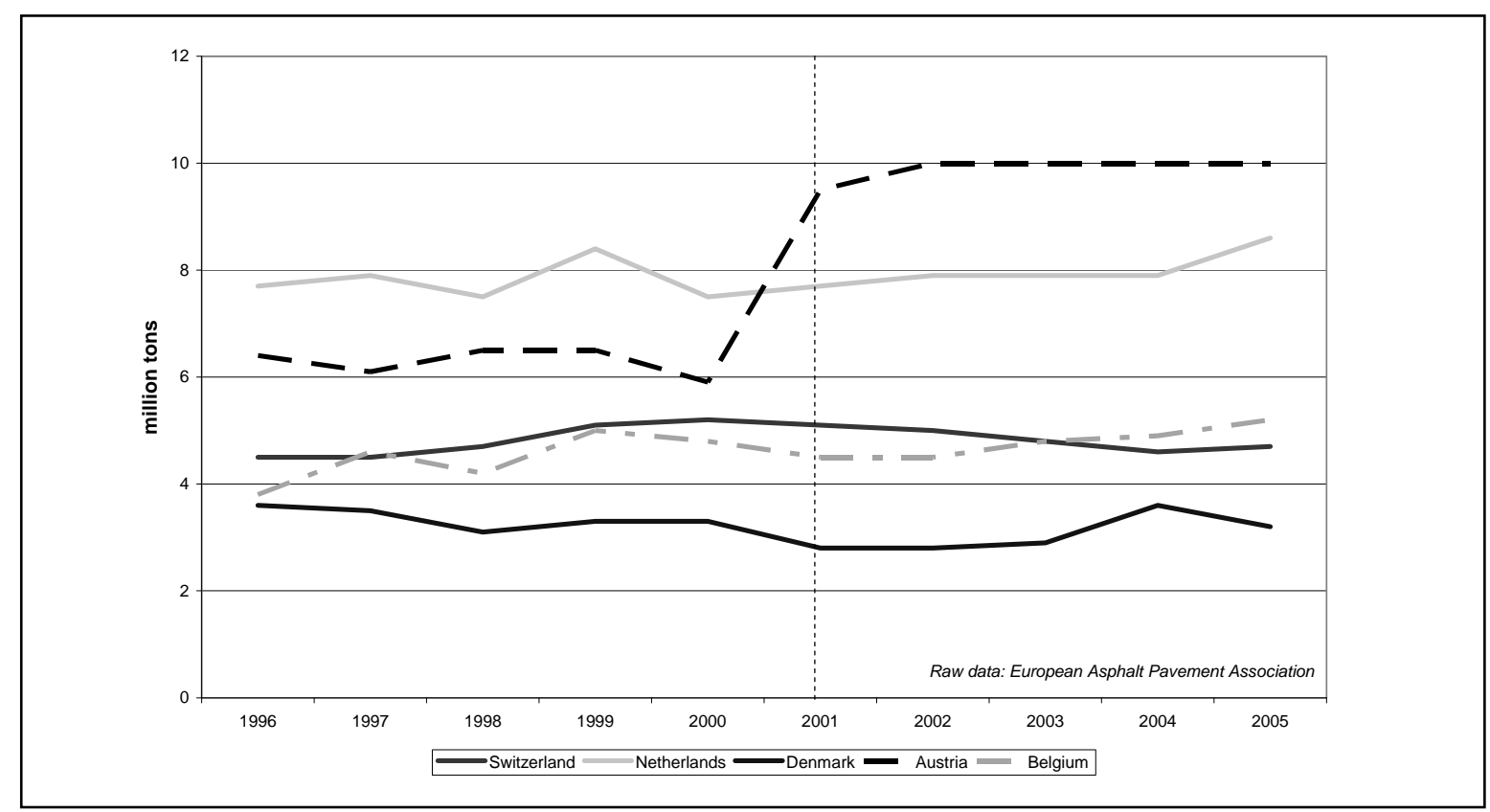

Figure 3. Production of Hot Mix Asphalt from 1996 to 2005 in smaller European countries.

As it can be seen in Figure 3, a comparison of the production development in Switzerland to other small European countries shows similar and relatively constant production outputs, although partly on quite different absolute levels. Changes due to the disclosure of the cartel are not observable in Switzerland. Only a considerable increase of the production in Austria at the beginning of the new millennium can be stated. This increase could be explained with the commissioning of a large new production plant. Already a small mobile mixing plant can achieve an output of approx. 200t/h leading to an annual output of approx. 0.4 million tons (assuming 250 working days à $8 \mathrm{~h}$ ).

A further important parameter in the characterization of the supply-side market structure is the number of the production plants. From a technical perspective, fixed and mobile plants can be differentiated. Fixed plants typically have a considerably larger capacity than mobile plants. Generally, the more production plants are available in a specific region, the more likely is competition with other plants and the lower is the expected market price. Figure 4 displays the development of the number of production plants in Switzerland. 


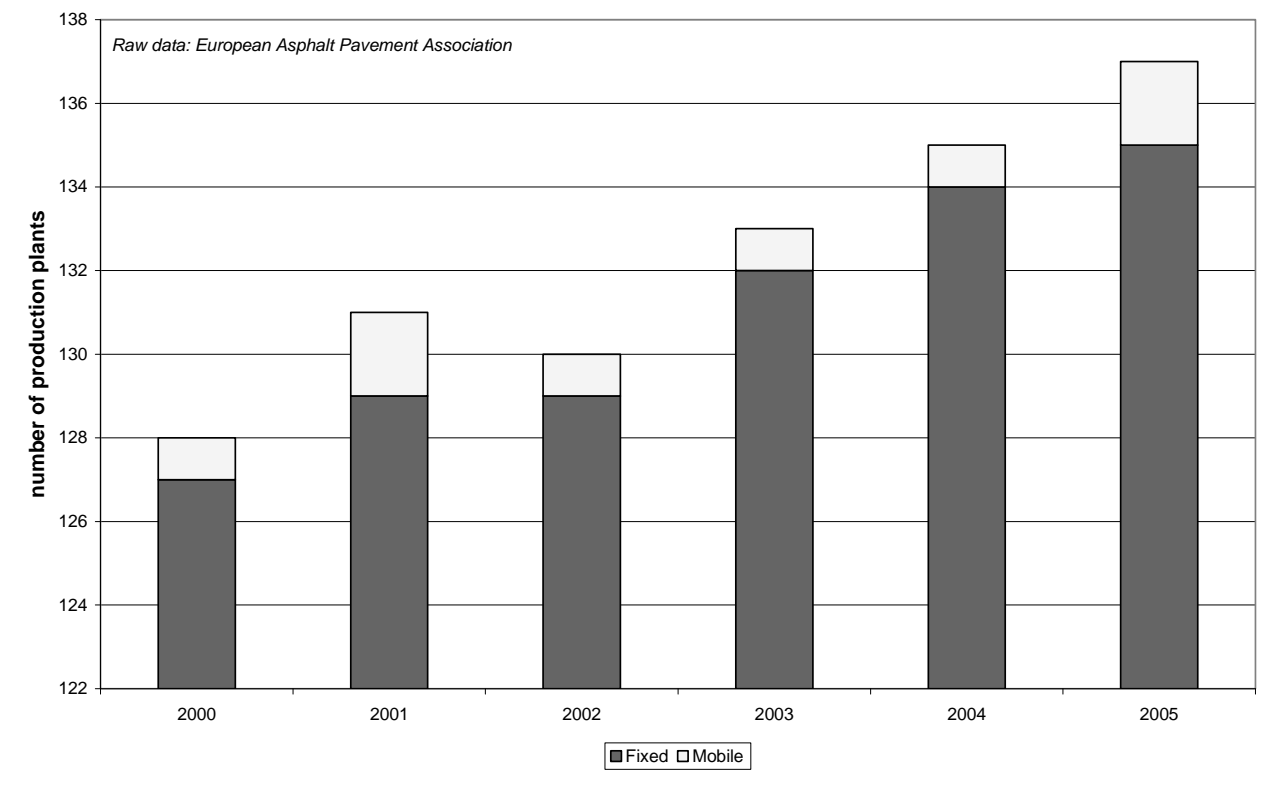

Figure 4. Number of production sites in Switzerland (2000-2005).

As Figure 4 shows, the number of production plants (fixed and mobile) in Switzerland has increased from 128 in 2000 to 137 in 2005 . This increase of about $7 \%$ is considerably higher than the European average of about $2 \%$. This seems surprising as - for the same time period - the data shows a negative growth of Hot Mix Asphalt production in Switzerland. Subject to the location and the ownership structure of the production plants, this development could stimulate competition in the market. However, the question whether total production capacity has increased due to the increase in production sites cannot be answered with the available data. It cannot be excluded that, for example, large inflexible plants have been closed down and replaced by small and more flexible ones. Should the observed growth have taken place without the closing of old plants, an increase in excess capacity in the Swiss domestic market and a respective pressure on market prices can be expected. In the medium and long term, such a market situation would possibly trigger either market exits or cartel formation (in order to reduce the prevailing rationalization pressure). Additionally, Figure 4 shows that mobile plants do not play a major role in Switzerland. Usually they are more frequently used in geographically very spacious countries such as Norway, Sweden and Finland.

Besides the number and growth of the production plants in Switzerland and other European countries, the data also allows comparing the number of production sites per company across various European countries (see Figure 5). An analysis of this data might give additional information on the prevalent industry structure. 


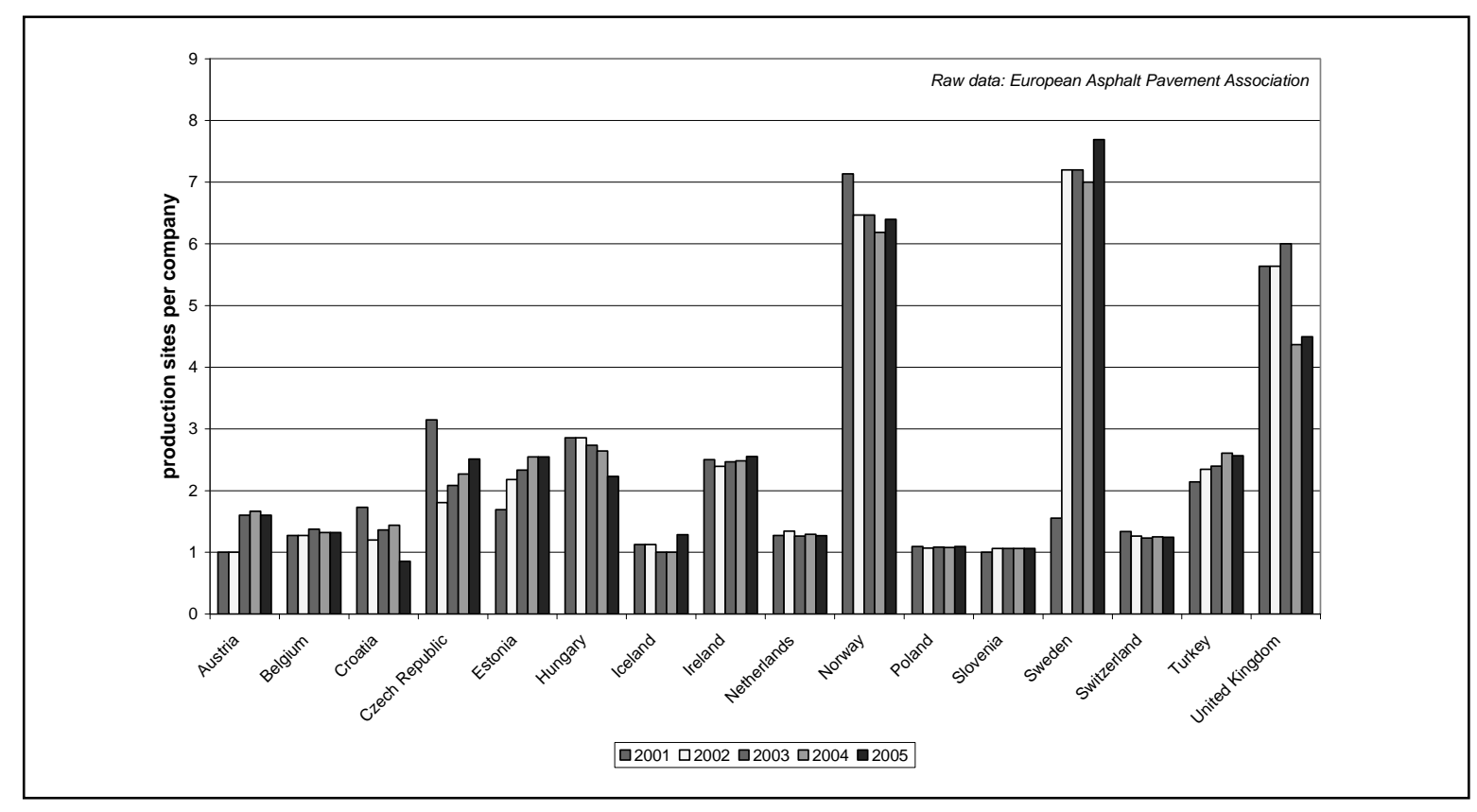

Figure 5. Average number of production sites per company (2001-2005).

As shown in Figure 5, the average number of production sites per company in Switzerland is slightly above 1 and therefore rather low in a European comparison. Again, it would be thinkable to conclude from this finding that competition should at least be possible in Switzerland given the fact that most companies only have one production site. However, it needs to be taken into account that the above figure may feign a decentralized industry structure in Switzerland, as the existing industry structure with several key holding companies (see Figure 1 above) might not be reflected in the data. Figure 5 further shows that in Norway and Sweden, large 'asphalt corporations' seem to dominate large parts of the country. This might have facilitated the cartel formation in these countries which was identified in Section III.C. above.

Still aiming at assessing the potential for competition in the Swiss road surfacing market, the following Figure 6 compares the number of production sites to the length of the road network for various European countries. Ideally it could be assumed that the number of production sites increases with the length of the road network. Furthermore it could be argued that countries with a relatively high number of production sites have a higher competition potential than comparable countries with less production sites. 


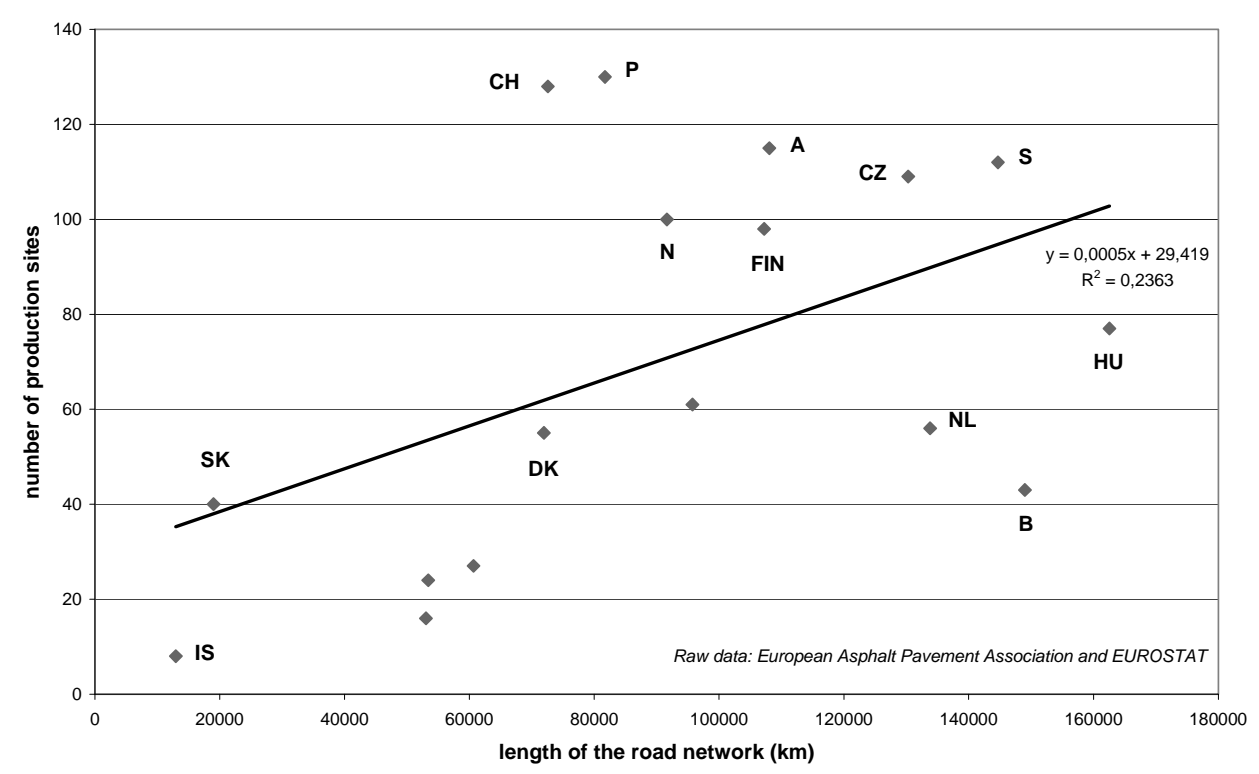

Figure 6. Number of production sites and length of the road network (small European countries).

Figure 6 shows the expected positive relationship between the length of the road network and the number of production sites. It shows further that Switzerland has a large number of production sites relative to the length of their road network. This is especially remarkable in direct comparison to the topographically similar Austria.

A further important parameter in a characterization of the supply-side market structure is the degree of the vertical integration of firms operating in the market for road surfacing. Generally three alternative states can be distinguished. A company can either specialize in asphalt mix production or specialize in road surfacing. The third type consists of companies who are active in both areas. The dataset allows an analysis of the degrees of vertical integration across several countries in Europe. The data shows that the number of companies operating exclusively in asphalt mix production show huge variations across countries. There are European countries where almost no independent asphalt mix manufacturers exist, whereas in other countries they seem to play a major role. In Switzerland, the number of firms being active only in the asphalt mix production is relatively high and it has increased even more during the last couple of years. One of the main reasons why this observation might at least partly mask the truth lies again in the holding structure of the Swiss road surfacing market. It is unclear whether the data set possibly identifies asphalt mix manufacturers as independent, although they are as a matter of fact part of the holding structure identified above.

The relative number of companies being active exclusively in the asphalt mix production should to a certain degree correspond to the relative number of companies active only in road surfacing. The analysis of the data shows that this is the case for Switzerland. A relatively high number of companies specialized in asphalt mix production is accompanied by a relatively high number of companies operating only in road surfacing. This trend is also observable in other European countries.

In addition to an analysis of the number of firms active in either the production of asphalt mix or road surfacing, the complementary data for vertically-integrated companies needs to be assessed. The data shows that the number of companies in Switzerland offering both asphalt mix production and road surfacing is relatively high compared to other European countries and has steadily increased since 2001 . 
Taking into account all data on the vertical structure of the road surfacing industry, it is possible to calculate an indicator which measures the degree of vertical integration. The respective results are displayed in Figure 7.

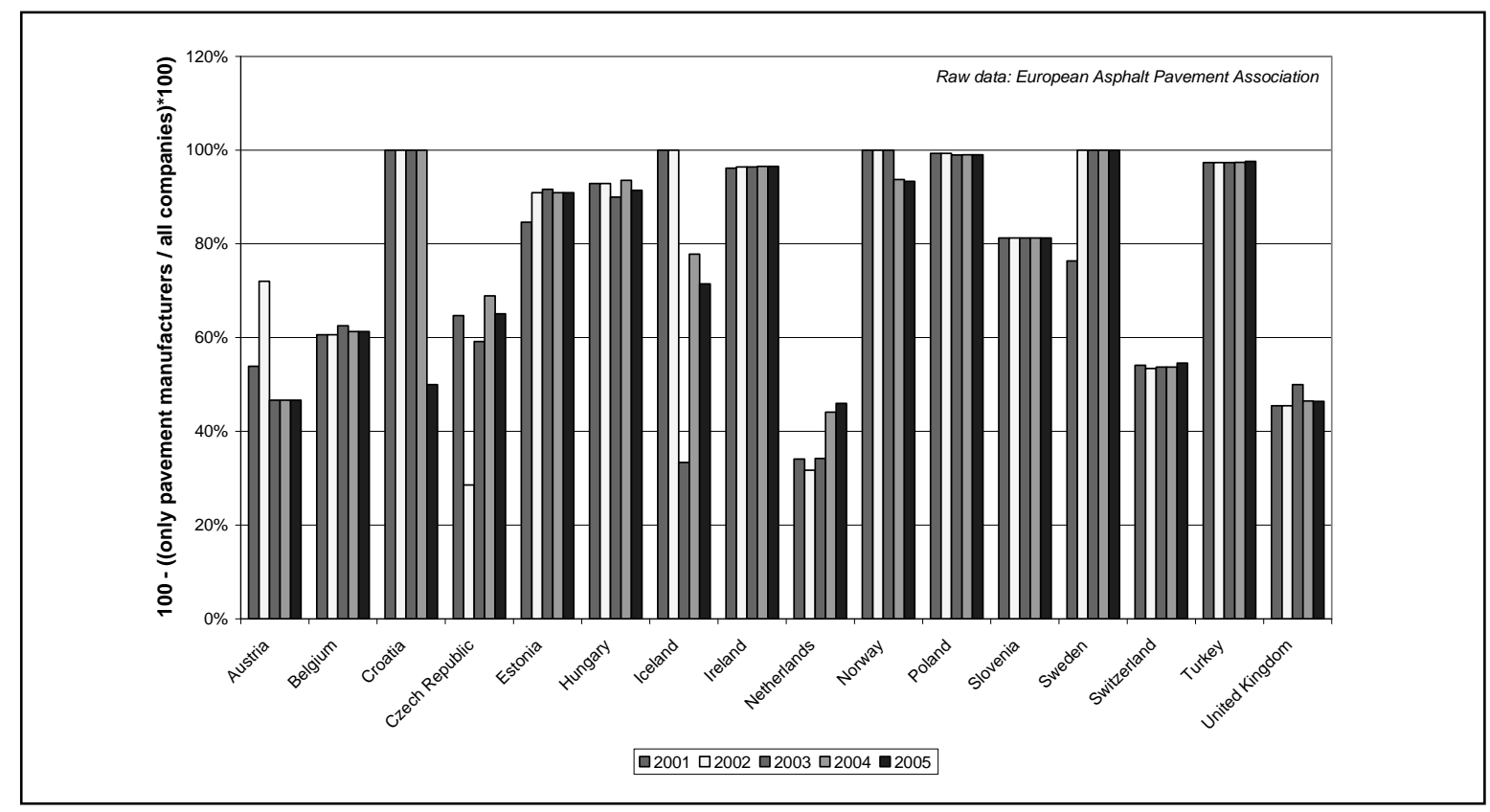

Figure 7. Degree of vertical integration in the road surfacing industry (2001-2005).

The degree of vertical integration displayed in Figure 7 is calculated as $100-((P / N) * 100)$ where $P$ is the number of firms producing only asphalt mix and $N$ is the total number of companies. This means that a country without any explicit independent asphalt mix manufacturers, for example, has a degree of vertical integration of $100 \%$. Switzerland with approx. $55 \%$ shows a relatively low degree of vertical integration in comparison to other European countries. However, it needs to be reminded that the value of this data remains unclear as it is not known whether or to what extent the existing holding structure is reflected.

\section{International trade}

The previous section compared the Swiss domestic market for road surfacing with other domestic European markets. On this high level of aggregation it is unlikely that the cartel agreement described in section III.B. - mainly concerning only a few cantons - led to noticeable effects on market structure parameters. However, especially the fact that the EDA was directly aimed at preventing imports of cheaper asphalt mix from Germany to Switzerland makes it straightforward to analyze the international trade of asphalt mix between Germany and Switzerland before, during and after the termination of the cartel agreement. From an economic theory perspective, an increase in the import of cheaper asphalt mix from Germany to Switzerland can be expected subsequent to the prohibition of the EDA. Ideally, trade takes place until a uniform market price has been reached. However, the limited transportation possibilities of the asphalt mix and the varying demand locations (i.e. construction sites) make German (and Austrian) asphalt mixes imperfect substitutes. Thus, in practice a certain price difference between Germany and Switzerland can still be expected. Furthermore, the holding structure - which was not affected by the termination of the cartel - can act as another explanation why prices in Switzerland remain higher in the post-cartel phase.

Given these straightforward hypotheses, the empirical approach basically needs to study the export time series for asphalt mix from Germany to Switzerland. In principle, two different sources of foreign trade data for Germany are available. On the one hand, the Federal Statistical Office in Wiesbaden collects relevant data for entire Germany. On the other 
hand, every German Federal State (called 'Bundesländer') also collects respective export statistics. In the following, the data of the Statistical Office of the Federal State of BadenWürttemberg is used basically because international trade of asphalt mix with other Federal States in Southern Germany (most notably Bavaria) is factually impossible given the geographical position in combination with the explained specifics of asphalt mix with respect to transportation. ${ }^{53}$ Therefore, Figure 8 shows the export of asphalt mix from BadenWürttemberg to Switzerland from 1983 to 2005 in volume and value numbers as well as the average price which can easily be derived from these numbers.

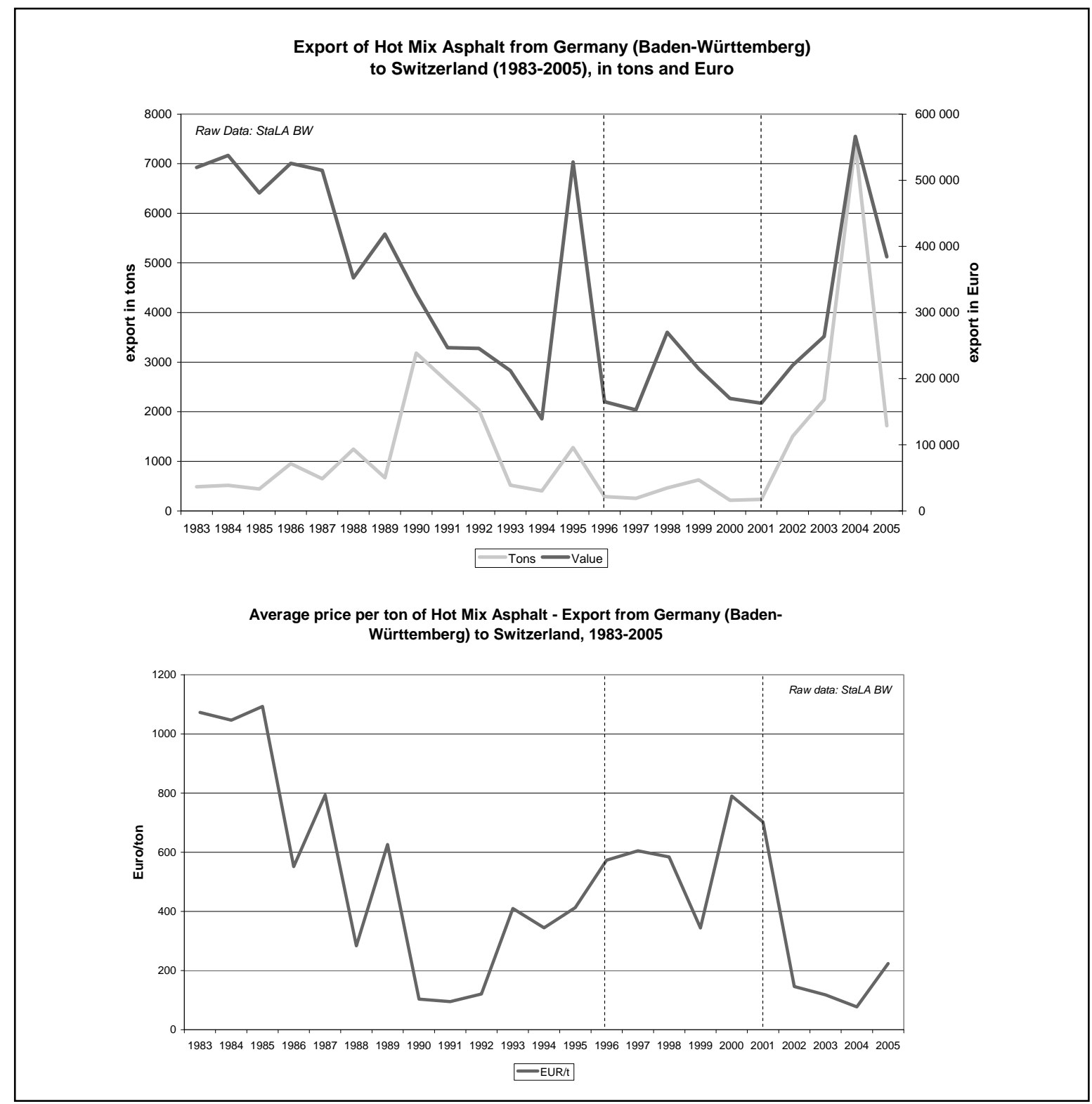

Figure 8. Export data and average price per ton of Hot Mix Asphalt from Germany (Baden-Württemberg) to Switzerland (1983-2005).

Figure 8 shows a very low absolute export level for asphalt mix, never exceeding 8,000 tons per year and with an average export level significantly below this value. Compared to the level of the domestic production in Switzerland of around 4.7 million tons, the imports from Germany therefore contributed only less than $0.2 \%$ to the Swiss demand of asphalt mix. Further interpreting Figure 8, two significant increases in export activity are notice-

\footnotetext{
${ }^{53}$ It should be remarked here that the analysis in the report was undertaken for both data sources. Surprisingly, both datasets differ substantially with respect to the size of international trade, however, not so much with respect to the pattern of international trade.
} 
able - one in the early nineties and one in 2005 . In both cases, it is likely that construction sites near the German border explain this increased export activity. A comparison of the export time series in volume and value (in Euro) is insofar noticeable as a strong correlation exists between both time series since the early 1990 (which was not observable before). However, much more important, Figure 8 shows a noticeable decrease of export activity (in volume and value) during the period from 1996 to 2000 in which the cartel agreement was implemented. After the detection and termination of the cartel an increase in the export activity of asphalt mix can be observed. Although there is no way with the data at hand to further substantiate a possible causality between the cartel agreement and the decrease during or the increase in export activity after the cartel agreement, Figure 8 at least indicates that this might have played a role.

Given that trans-border operations only mark a little share of a company's business, it is not surprising that export shares show a high volatility, since exports may depend on single projects. As Figure 8 additionally shows, the average price per ton of export of Hot Mix Asphalt to Switzerland shows a strongly decreasing trend until the beginning of the nineties. The period between the early nineties and the termination of the cartel in 2001 is characterized by considerable price increase. The years after the cartel termination again show a significant decrease of the average price per ton for exports to Switzerland. Here, basically the same conclusion can be given than above with respect to the volume/value figures. Again, the time series in Figure 8 does not exclude the presumption that the termination of the cartel led to increased competition and therefore to a reduction in the average export price. However, as before, there is no way to further substantiate a possible causality with the data available.

\section{B. Demand-side analysis}

The natural complement to the analysis of the supply-side in the last section is the analysis of the demand-side of the market for road surfacing in Switzerland. In this respect, the case description in section III.B. above already indicated that the direct customers of asphalt mix manufacturers are the road construction companies using it as key input. The services of the road construction companies are in turn demanded to a great extent ${ }^{54}$ by the official contracting authorities who are responsible for road maintenance and road construction in Switzerland. As a consequence, the demand side of the market for road surfacing is basically defined by the construction expenses of the Swiss contracting authorities. The allocation of this demand to the various road construction companies is usually carried out in the form of tenders.

A first look at aggregated demand data for Switzerland collected by the Federal Statistical Office (BFS) shows that the expenses for the construction of new roads by contracting authorities sum up to more than CHF 4 billion per year. Between 1997 and 2000 a slight demand increase can be observed, however, the overall demand is relatively stable over time. More insightful than analyzing aggregated demand data on state level is an analysis of the respective data for the seven main regions of Switzerland (Eastern Switzerland, Zurich, Central Switzerland, Northwestern Switzerland, Espace Midland, Lake Geneva region and Ticino) which is also collected by the BFS. Figure 9 displays the expenses for road construction of the contracting authorities in the Swiss main regions from 1998 to 2005 at current prices.

\footnotetext{
${ }^{54}$ The private demand for road surfacing is so low that it can be disregarded in the following.
} 


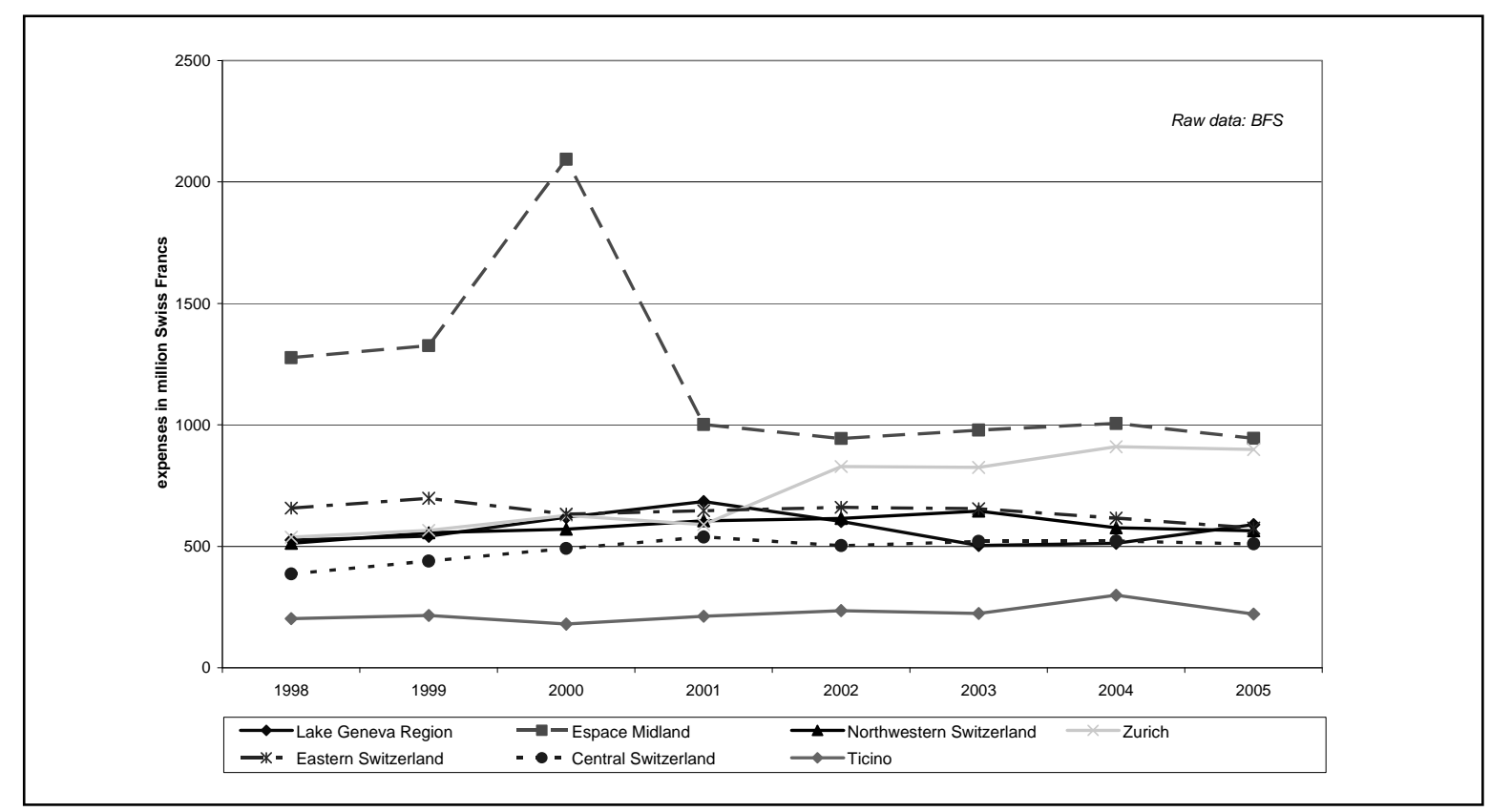

Figure 9. Expenses for road construction of contracting authorities in the Swiss main regions (1998-2005).

As shown in Figure 9, the road construction expenses of contracting authorities for road construction in the Swiss main regions are only partly discontinuous. Besides the temporarily high expenses in the Espace Midland region, the expenses in the Zurich region rose over several years. However, most other regions do not show drastic year-on-year changes in their expenses for road construction.

Given the fact that the cartel agreement focused on particularly three cantons, it is sensible to further reduce the level of aggregation and to analyze the demand development for the three single cantons primarily affected. Figure 10 therefore shows the respective investments of the contracting authorities in road construction in the cantons of Schaffhausen, Thurgau and Zurich.

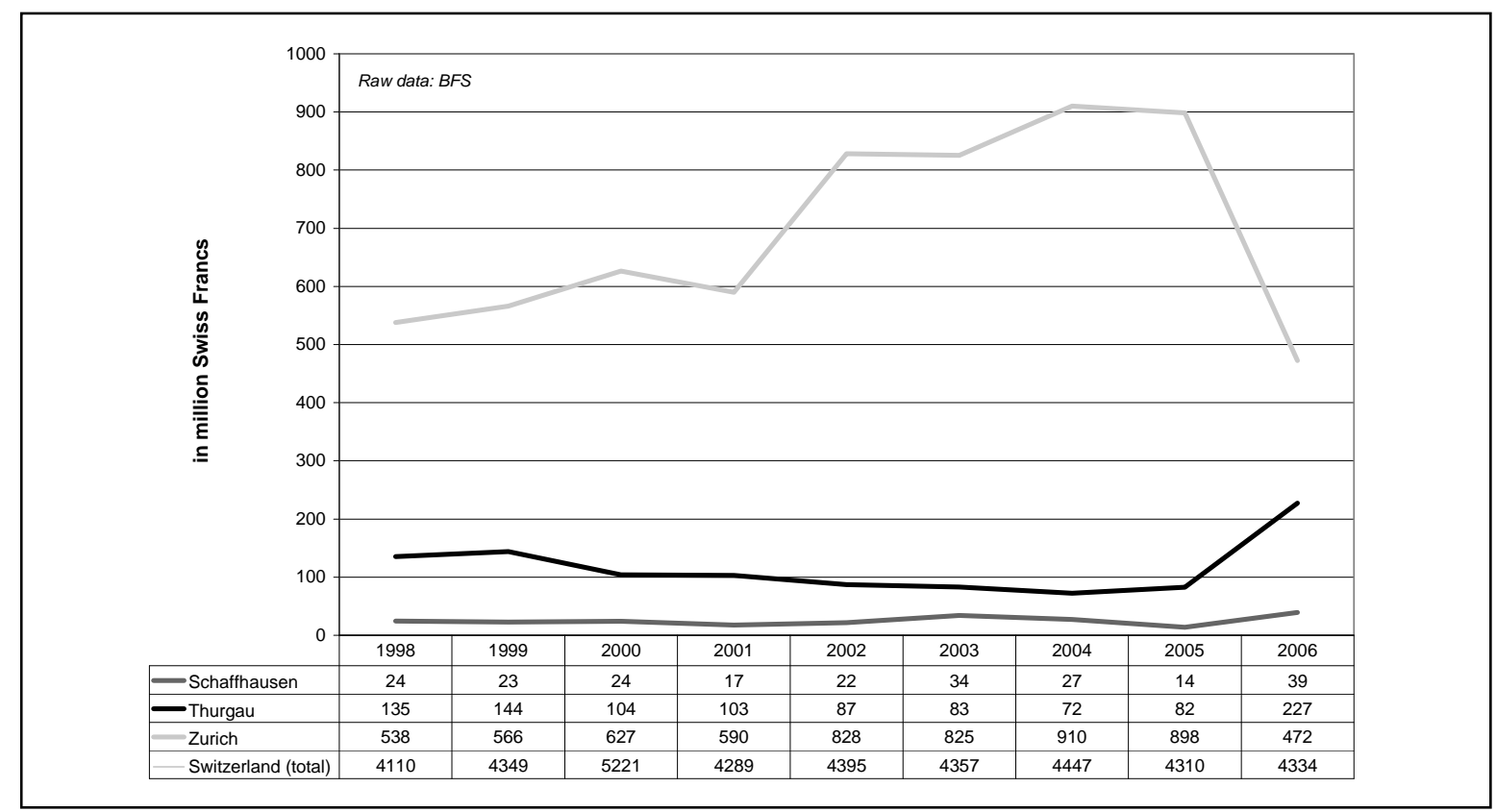

Figure 10. Investments of contracting authorities in road construction (1998-2006) for selected cantons. 
As Figure 10 shows, the cantons affected by the agreement are characterized by very different investment levels for road construction (mainly caused by their different canton and therefore road network sizes). In the canton of Zurich the construction expenses increased over a couple of years, however, in 2006 they were reduced nearly by half. Also in the canton of Schaffhausen an increase of investments is observable in 2006.

In addition to the isolated presentation of the demand data of the respective main regions or cantons, a comparative analysis of the development of demand and prices over time is of key interest from the economic point of view. In an ideal market it can be expected that an increase in price leads to a reduction in demand and vice versa. Therefore, any price cut due to the termination of the cartel agreement would then have to lead to a corresponding increase in demand. The size of the increase would be dependent on the prevalent demand elasticity. In order to investigate, whether this essential economic mechanism can be found in the data at hand, the following figures compare the respective time series of the public expenses for road construction (demand) and the building price index $^{55}$ (price) for selected main regions from 1998 to 2006.

As shown in Figure 11, the graphs for the main regions Zurich, Ticino and Central Switzerland show no uniform pattern. In the main region of Zurich a reduction in the price index is accompanied by an increase of the expenses for construction. In this respect, the data confirms the theoretical argument derived above. However, focusing on other regions leads to immediate disillusion. For example, in Ticino, constant increases in the price index are accompanied by constant increases in the expenses for road construction. However, it needs to be reminded that another type of road surfacing cartel was active in Ticino at the time and the data might simply reflect the existence of this cartel (see section III.B. above). Equally noticeable are the time series for the Central Switzerland region. Both time series seem to be highly correlated and show neither a significant change in expenses nor the price index.

Overall, demand-side analysis does not seem to be very helpful for an analysis of the possible effects of the cartel in the market for road surfacing. Although the region of $\mathrm{Zu}$ rich (which was affected by the cartel agreement) shows a significant switch after the termination of the cartel, it must be doubted that the cartel had a significant influence on this development. Unlike most consumer markets, the demand for publicly funded projects such as road construction might be highly price-inelastic in the short and medium term due to inertia and other constraints within the contracting authorities. These authorities typically plan with a fixed budget several years in advance and savings from lower expenditures in single projects cannot be immediately shifted into additional construction projects.

\footnotetext{
${ }^{55}$ A more specific explanation and analysis of various building price indices follows in section IV.C.
} 


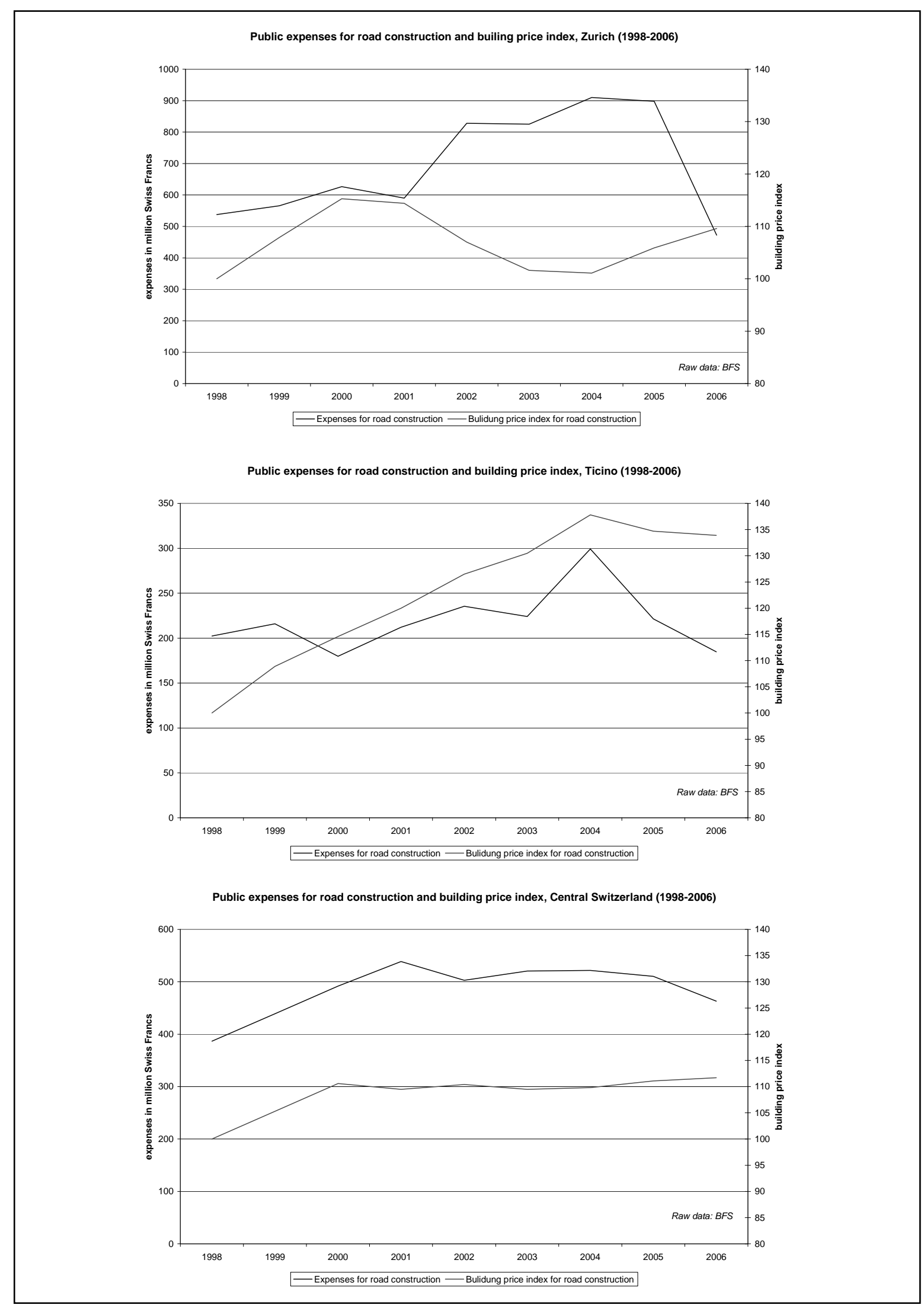

Figure 11. Public expenditures and the price index for road construction.

\section{Price analysis}

Following the analysis of the supply- and demand-side of the market for road surfacing in Switzerland, the investigation is completed with an analysis of the price developments before, during and after the cartel agreement. Generally and also referring to the existing lit- 
erature sketched in section II.C. above, noticeable price reductions would be expected after the termination of the cartel. The following analyses have the aim of investigating this hypothesis. Unfortunately, data is not available on a regional level but again only for the main regions of Switzerland. This is problematic for the desired identification of cartel effects because Schaffhausen and Thurgau are only two cantons within in the significantly larger main region of Eastern Switzerland. The main region of Zurich thus seems to be the preferred object of analysis; however, the problem that arises here is that large parts of the region are too far away from the Germany to be considered as potential distribution area for these asphalt mix manufacturers.

Despite these analytical drawbacks, a general analysis of the price developments for the construction of new roads is possible via the so-called building price index which is calculated by the BFS. ${ }^{56}$ The building price index is an indicator which reflects the development of the effective market prices of domestic companies operating in the construction industry. The index therefore reflects both the cyclical movements of supply and demand and possible productivity gains. The index is surveyed semi-annually and provides result for the construction industry as a whole, but also for three subtypes of superstructure activities (new construction of office buildings, new construction of dwellings, new construction of wooden dwellings and renovation of dwellings) and two subtypes of substructure activities (new construction of road parts and new construction of underpasses). The indices are calculated for the seven main regions of Switzerland. The prices which form the basis of the index are taken from contracts effectively concluded from January to April or from July to December, respectively. Approximately 3.000 companies provide approx. 30.000 prices for the respective survey period. The collected prices are then translated into elementary indices, i.e. only the prices of the same company for the same services are compared from one survey period to another. In order to calculate the price development of a particular construction work, the arithmetic mean of the elementary indices is calculated. Then, the indices of the different services are summed up in order to generate the total index for all types of construction work in the various main regions. Figure 12 shows the general building price index for various object types for Switzerland from 1998 to 2007.

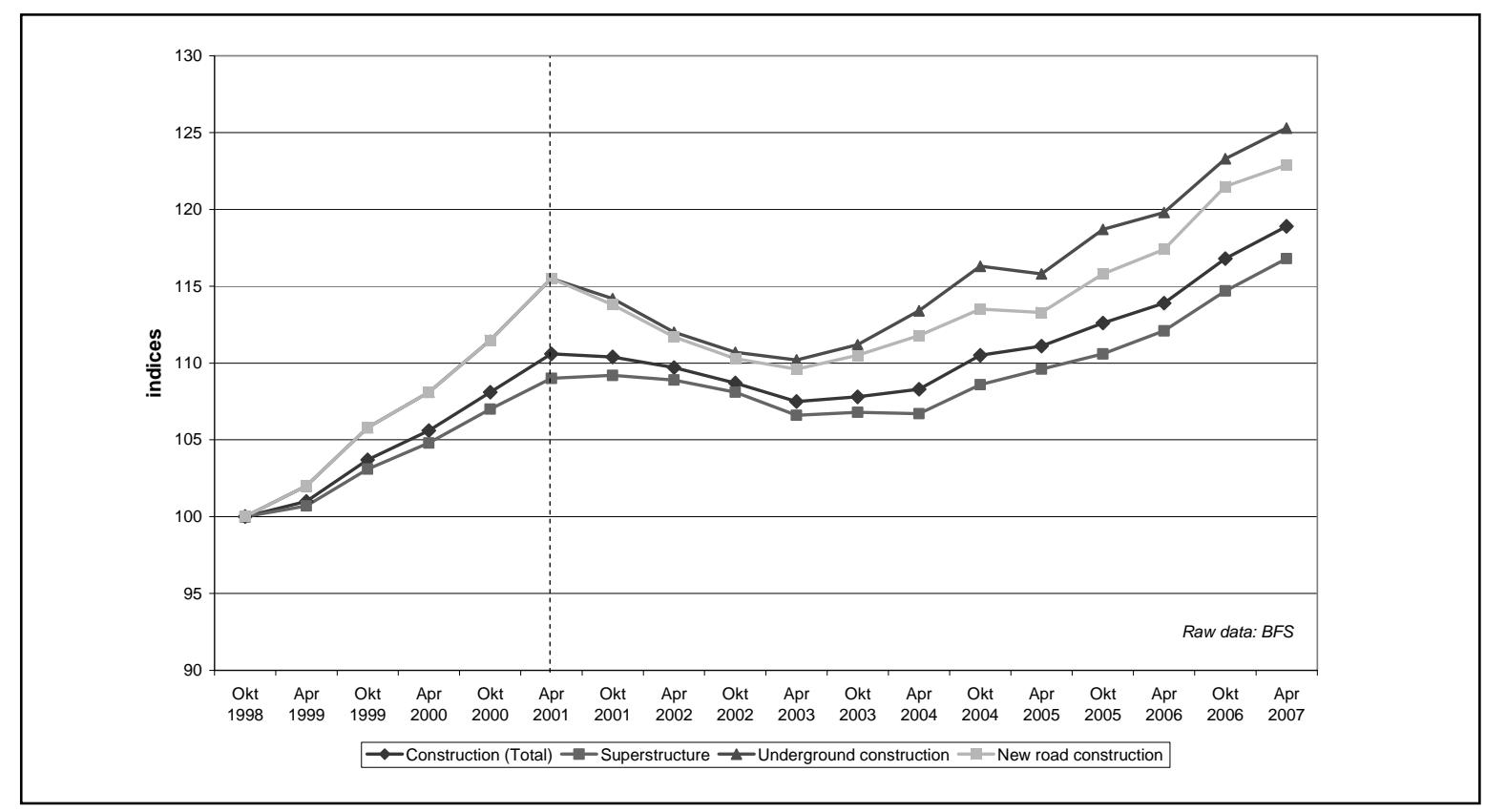

Figure 12. Building price index for various object types for Switzerland (1998-2007).

As shown in Figure 12, the general building price index increased from 1998 to 2001 and experienced a drop from 2001 to 2003. Since then, the index again shows a continuously

\footnotetext{
${ }^{56}$ See Steffen \& Guillod (2004).
} 
increasing pattern across all object types. The price increases in new road construction have been less significant than in case of underground construction, however, they lie above the average of all construction works. In principle, Figure 12 would allow the allegation that the termination of the cartel in 2001 led to the significant drop in the price index in the following years. However, due to the fact that these reductions in the price index can also be observed for other objects types with no connection to the cartelized market, there must have been other factors which explain the observed reduction in the price index.

As a consequence, for the study of the effects of the cartel on market prices, the examination of the sub-index 'construction of new roads' in selected main region is certainly more significant. This sub-index - shown in Figure 13 - is also calculated by the BFS with road surfacing work taking a weight of $25 \%$ in the sub-index.

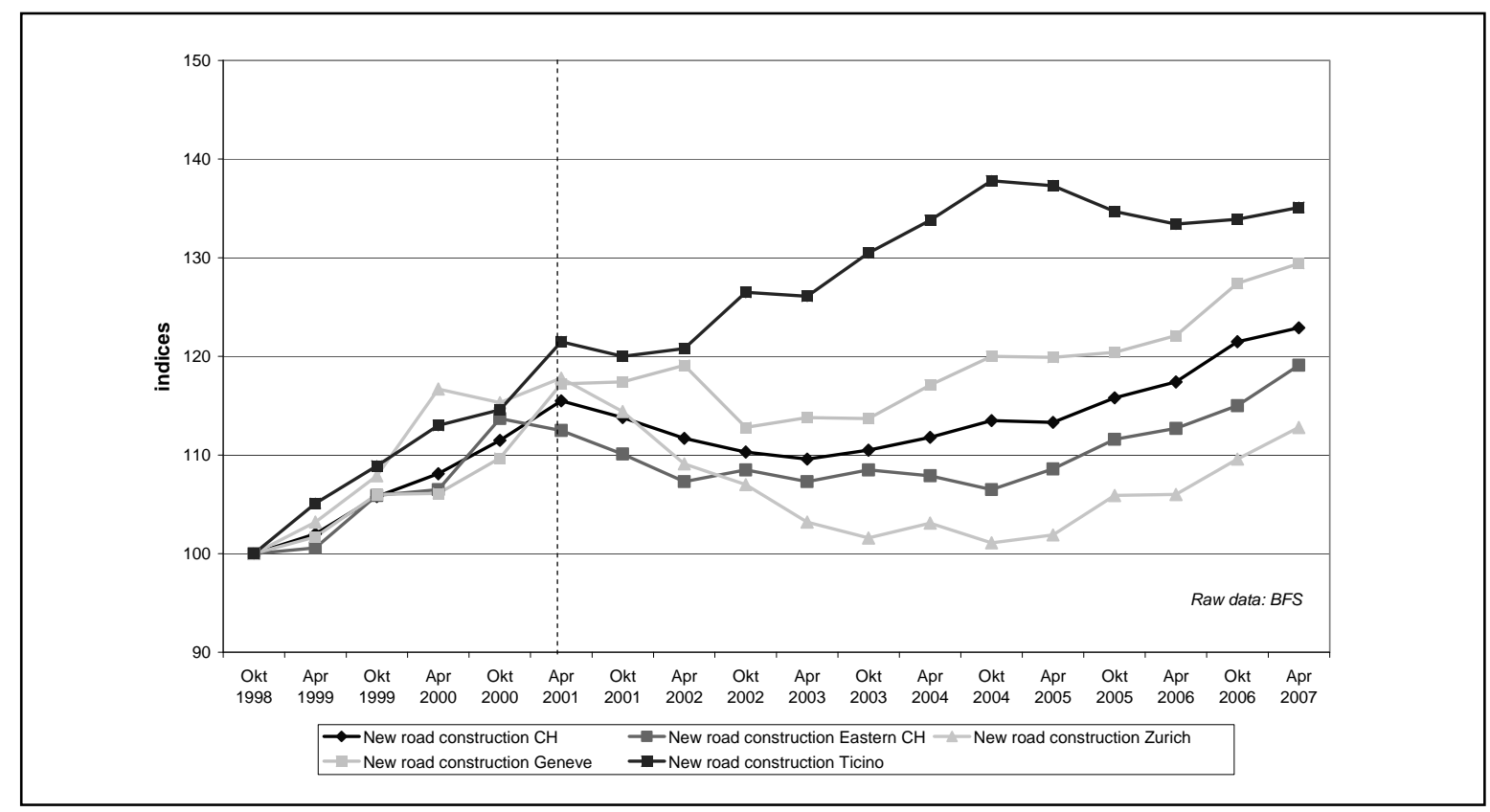

Figure 13. Building price index for new road construction in Switzerland and in the Swiss main regions.

According to Figure 13, the already identified decrease in the price index from 2001 to 2003 is also observable in most of the regions here. However, in the main regions which were directly impacted by the cartel (i.e. Zurich and Eastern Switzerland), the downward trend seems to be stronger than in other main regions. Furthermore, again the time series for Ticino is noticeable as the 2001-2003 downward trend of the price index is not observable there. Again, the most straightforward explanation is simply the existence of another type of cartel in the road surfacing market (see section III.B. above).

Although Figure 13 already allowed a relatively specific view thanks to the provision of a separate sub-index for new road construction, the data made available by the BFS even allows a further specification of the analysis as - again on the level of the Swiss main regions - a sub-sub-index 'road surfacing' is also available. The respective values are plotted in Figure 14 for selected main regions from 1998 to 2007. 


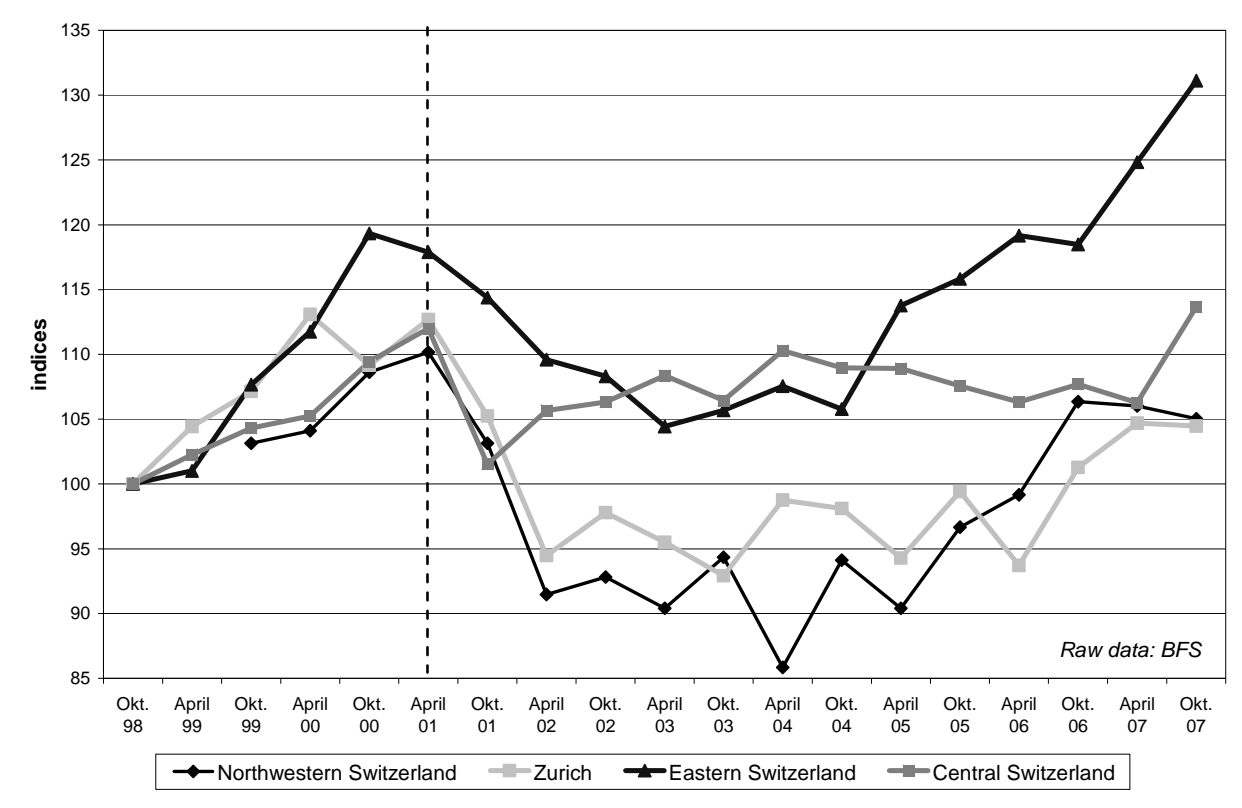

Figure 14. Building price index for road surfacing in selected Swiss main regions.

Generally, Figure 14 does not differ substantially from the more aggregate price index 'new road construction' just discussed. Again, the figure shows the decrease in the price index starting in 2001. However, the decrease of the index in the main regions Zurich and Northwestern Switzerland is much more noticeable than in the more aggregated price indices. One possible explanation for these significant price reductions in road surfacing can be seen in the termination of the cartel, however, a potential causality cannot be investigated more closely with the data at hand. ${ }^{57}$ Furthermore, it can be observed that the price index in all main regions except Central Switzerland began to rise again after a period of decreases or at least roughly constant devolution.

\section{ESTIMATION OF THE ECONOMIC EFFECTS OF THE DECISION}

As already mentioned above, numerous empirical studies come to the conclusion that the prosecution of cartels makes a great contribution to the positive welfare effects of competition policy as a whole. Even though most of the benefits likely result from the (hardly quantifiable) deterrent effect and thus the ex-ante prosecution of cartels, the analysis of the factual consumer and 'deadweight' losses can provide valuable insights into the effects of cartel prosecution. The welfare effect can then be measured as the present value of the welfare loss from an ongoing cartel absent an effective competition policy intervention.

The approach of quantifying the mentioned effects, neglecting the 'deadweight losses', is simple and conservative. Based on the observed (increased) cartel price a so-called 'butfor' price must be determined which would prevail if the companies had refrained from the cartel agreement and acted competitively instead. The difference between the actual price and the 'but-for' price must then be multiplied by the output quantity (for the total time of the cartel) in order to deduce an assessment of the cartel effects on consumer welfare.

Although this technique to quantify the cartel effects appears to be relatively simple, numerous obstacles must be overcome in practice. Sometimes it is difficult to fix a uniform market price, to detect the exact duration period of a cartel, to determine the passing on of the increased costs downstream or the inclusion of taxes into the analysis. A particular challenge is usually the derivation of the 'but-for' price, partly because the respective final

\footnotetext{
57 Another possibility to investigate competition intensity would be to compare the price development in Switzerland with the price developments in neighboring countries. Although respective price indices are calculated in many countries, they can hardly be compared to Switzerland due to different calculation principles and concepts.
} 
results mostly are very sensitive to small changes of the 'but-for' price. For the purpose of an estimation of the 'but-for' price the literature offers various methods, each of which is strongly dependent on the data available. One possibility is the use of market prices, which were observed before the formation of the cartel in the relevant market. Otherwise, it may be possible to analyze comparable markets to derive 'but-for' prices. Furthermore, homogeneous and heterogeneous oligopoly models can be used to receive competitive market prices by applying simulation tools. Moreover, sometimes it is possible to derive 'but-for' prices from cost data (supplemented by a reasonable return on investment).

In the present case of road surfacing, quantification as described above is not possible or reasonable, respectively. This is mainly due to two aspects. First, the regional data necessary for the quantification is not available. Second, the case study shows no clear indication that the collusion-friendly industry structure has significantly changed in the aftermath of the decision. Thus, it is unclear whether the decision has directly caused a significant decrease in market prices.

While a direct quantification of the effects of the decision is not sensible, it is possible to give a rough estimate of the potential benefit of a competition policy intervention. For this purpose, it is assumed that the increased cartel price for one ton of asphalt mix (ex factory) is CHF 130. It is further known from empirical studies that the average surcharge of horizontal cartels amounts to approx. $30 \% .{ }^{58}$ If we accept this average value for a road surfacing cartel it follows that the competitive price (the so-called 'but-for' price) would be $\mathrm{CHF}$ 100. Thus, the price difference between the cartel price and the competitive price would be CHF 30.

In order to roughly quantify the cartel effect, the effective demand at the increased cartel price must be determined. In 2005, the total asphalt mix production in Switzerland amounted to approx. 4.7 million tons. Since the international trade of asphalt mix is insignificant, we assume in the following that the entire quantity was sold on the domestic market. The cartel operated mainly in the cantons of Schaffhausen, Thurgau, and Zurich. Although the individual levels of demand for asphalt mix are unknown, we know that the total investment volume in 2005 for Switzerland in the industry of road construction was about 4.31 billion CHF. Out of this total investment budget approx. 994 million CHF or approx. 23\% were allotted to the three cantons. Assuming that the regional allocation of the investments is proportional to the quantity of processed asphalt mix, it results in an amount of processed asphalt mix of 1,083,944 tons. For an increased cartel price of CHF 130 the costs for asphalt mix in these three cantons amount to CHF 140,912,761. For the competitive price of CHF 100, however, the costs would result in CHF 108,394,432. The difference of CHF 32,518,329 thus describes the highest possible contribution of competition policy which is realized when after the termination of the cartel agreement the market price falls to the competition level and the cartel price has been $30 \%$ above this price. In practice this means that the costs for the customers for road surfacing ideally would decrease by approx. CHF 32 million. However, it should be pointed out that this amount would be the highest possible (efficient) reallocation from the manufacturers to the customers. The so-called deadweight loss, i.e. the decrease in demand due to excessive prices, is not yet included in this calculation. Ballpark figures exist also here, settling the deadweight loss in the range of $10-30 \%$ of the surplus gains. ${ }^{59}$ However, since in this case the demand is expected to be relatively inelastic, the deadweight loss can be expected to be clearly below this range.

As already mentioned before, it is disputable for several reasons that the decision of the COMCO had significantly decreased the price level in the road surfacing market or even beat it down to the competitive level. Especially due to the identified holding structure it is likely that the main direct economic effect of the decision must be seen in the regained

\footnotetext{
${ }^{58}$ See Connor \& Lande (2006).

${ }^{59}$ See Connor \& Helmers (2006).
} 
possibilities of the two independent road construction firms to purchase asphalt mix at lower prices from Germany leading to more competitive tender processes insofar as these firms are probably able to underprice the vertically integrated Swiss firms. This results in cost reductions for contracting authorities and, as a consequence, a reduction in the tax burden for the citizens. However, taking into account the limited capacities of both independent companies, it is unrealistic to assume that it is possible for them to participate in all tenders and therewith to promote competition substantially in the relevant cantons or even in entire Switzerland.

\section{VI.CONCLUSION}

There is no significant doubt among economists that competition policy has established itself in most industrialized countries as an integral part of public policy that contributes substantially to the improvement of the wealth of nations. However, the follow-up question of how substantial these benefits of competition policy have been has not yet attracted huge research input by economists. This 'state of the art' is unfortunate as, for instance, competition authorities have to justify their budgets (or requests for budget increases) and might find it helpful to show the significance of their work. Furthermore, economists also benefit from showing to what extent society benefits from their public policy recommendations.

Against this background, the paper aimed at assessing the question whether competition policy matters by analyzing the impact of the detection of a hard-core cartel in the Swiss market for road surfacing on post-cartel competition. In addition to an investigation of supply-side factors, demand-side factors, and market prices, the paper also derived estimates of the economic effects of the decision.

Overall, the policy implications from this case study can be inferred with regard to both the specific case at hand and cartel policy in general. With respect to the specific case, it was found that after the detection and prosecution of the cartel agreement, a decrease in the price indices for road construction and road surfacing were observed. However, the industry structure existing at the time of the cartel agreement - where road construction companies were jointly involved in mixing plants via holding companies - has certainly facilitated and sustained cartelization and there is no evidence of change in the past years since the decision. From this perspective it appears unrealistic that the decision of the COMCO alone has had substantial influence on the post-cartel market prices or important parameters of market structure. As already discussed in the last section, the presumably most important direct effect should be seen in the retrieval or at least in the improvement of the competitive position of the independent road construction firms. This intervention was successful insofar as both firms are still active in the market.

A possible and economically valuable effect of the case decision might be that firms generally or at least in the road surfacing industry become more cautious with respect to cartel formation. If the companies decide to reduce the actual cartel price by a small amount in order to reduce the probability of detection for the respective cartel agreement, the savings on the consumer side could already be substantial. In the hypothetical example above, a decrease of the price per ton by 5 Francs (from CHF 130 to CHF 125) would, for example, lead to annual savings in the amount of approx. CHF 5.419.722. It should be reminded that this value applies only to the three cantons directly affected by the cartel agreement and only refers to a relatively small market, namely that for road surfacing.

With respect to the implications for general cartel policy, one improvement possibility would be to carry out screenings to identify potentially collusion-friendly industries by using a set of collusion factors. Subsequently, these suspicious industries should then be investigated more closely focusing on market structure, market behavior and market results, possibly in the form of 'inquiries' conducted by the UK Competition Commission. Such an approach would not only raise the probability to detect cartels directly but it would 
also create a signal for the firms in the respective industries that they are on a watch. Ideally, one of the respective companies becomes nervous enough to decide to apply for leniency. A valuable side effect of such screenings and industry studies lies in the better knowledge of the respective markets and thus in the generation of knowledge which subsequently influences the quality and the pace of decision making within the competition authority.

However, screening should not be limited to the pre-evidence stage. Especially after the discovery of collusive behavior in a particular market, a constant monitoring is advisable, in particular if collusion-friendly industry structures remain effective. Imposing a closer monitoring of former cartel members with respect to their pricing strategies, cost structures, and cooperation in joint projects may be a proper instrument for an competition authority to prevent a reemergence of collusion even in tacit way. Furthermore, it follows immediately that any further concentration in these markets should be investigated very closely by the competition authority. Any merger either on the level of asphalt mixing or road construction should be cleared conditional on breaking up horizontal or vertical ties that might reinforce coordinated behavior. Overall, providing a large set of instruments and a large scope of discretion to the competition authority helps to create uncertainty that is detrimental to any kind of collusive activity among firms.

\section{REFERENCES}

P. Asch \& J. Seneca (1975), Characteristics of Collusive Firms, Journal of Industrial Economics 23, 223-37.

D. Audretsch (1989), Legalized Cartels in West Germany, Antitrust Bulletin 34, 373-394.

K. Bagwell \& R. Staiger (1997), Collusion over the Business Cycle, RAND Journal of Economics 28, 82-106.

G. Bittlingmayer (1992), Stock Returns, Real Activity and the Trust Question, Journal of Finance 47, 1701-1730.

M. Block \& J. Feinstein (1986), The Spillover Effect of Antitrust Enforcement, Review of Economics and Statistics 68, 122-131.

M. Block, F. Nold \& J. Sidak (1981), The Deterrent Effect of Antitrust Enforcement, Journal of Political Economy 89, 429-445.

D. Carlton \& J. Perloff (2000), MODERN INDUSTRIAL ORGANIZATION, Reading.

J. Clarke \& S. Evenett (2003), The Deterrent Effects of National Anticartel Laws: Evidence from the International Vitamins Cartel, Antitrust Bulletin 48, 689-726.

J. Connor \& G. Helmers (2006), Statistics on Modern Private International Cartels, 19902005, Working Paper, Purdue University, West Lafayette.

J. Connor \& R. Lande (2006), The Size of Cartel Overcharges, Antitrust Bulletin 51, 9831022.

P. Crampton (2003), Cartels as an International Competition Issue, Working Paper, PECC General Meeting 2003, Brunei.

A. Dick (1996), When are Cartels Stable Contracts?, Journal of Law and Economics 39, 241-283.

R. Feinberg (1984), Strategic and Deterrent Pricing Responses to Antitrust Investigations, International Journal of Industrial Organization 2, 75-84.

S. Feuerstein (2005), Collusion in Industrial Economics, Journal of Industry, Competition and Trade 5, 163-198.

P. Grout \& S. Sonderegger (2005), PREDICTING CARTELS, Economic Discussion Paper, Office of Fair Trading, London.

J. Haltiwanger \& J. Harrington (1991), The Impact of Cyclical Demand Movements on Collusive Behavior, RAND Journal of Economics 22, 89-106.

J. Harrington (2005), Detecting Cartels, Working Paper, Johns Hopkins University, Baltimore. 
K. Hüschelrath (2009), COMPETITION POLICY ANALYSIS - AN INTEGRATED APPROACH, Heidelberg.

K. Hüschelrath, N. Leheyda, P. Beschorner, G. Licht, S. Arvanitis, M. Wörter \& Heinz Hollenstein (2009), Fallstudien zu den Wirkungen des Kartellgesetzes, Bern.

M. Ivaldi, B. Jullien, P. Rey, P. Seabright \& J. Tirole (2003), THE ECONOMICS OF TACIT COLLUSION, Final Report for DG Competition, Toulouse.

J. Karpoff, D. Lee \& G. Martin (2008), The Cost to Firms of Cooking the Books, Journal of Financial and Quantitative Analysis 43, 581-612.

M. Levenstein \& V. Suslow (2004), What Determines Cartel Success?, Working Paper, University of Michigan, Ann Arbor.

J. Lipczynski \& J. Wilson (2001), INDUSTRIAL ORGANIZATION - AN ANALYSIS OF COMPETITIVE MARKETS, Essex.

M. Motta (2004), COMPETITION POLICY, Cambridge.

M. Neumann (2000), WETTBEWERBSPOLITIK. GESCHICHTE. THEORIE UND PRAXIS, Wiesbaden.

OECD (2007), REMEDIES AND SANCTIONS IN ABUSE OF DOMINANCE CASES, Paris.

OECD (2002), FIGHTING HARD CORE CARTELS, Paris.

L. Pepall, D. Richards \& G. Norman (2001), INDUSTRIAL ORGANIZATION: CONTEMPORARY THEORY AND PRACTICE, Boston.

A. Resch (2005), Phases of Competition Policy in Europe, Working Paper, Institute of European Studies, University of California, Berkeley.

P. Rey (2006), On the Use of Economic Analysis in Cartel Detection, EUI-RSCAS/EU Working Paper, Florence

G. Richardson (1965), The Theory of Restrictive Trade Practices, Oxford Economic Papers $17,432-449$.

J. Rotemberg \& G. Saloner (1986), A Supergame-Theoretic Model of Price Wars during Booms, Americian Economic Review 76(3), 289-407.

N. Schulz (2003), WETTBEWERBSPOLITIK, Tübingen.

M. Sproul (1993), Antitrust and Prices, Journal of Political Economy 10, 741-754.

G. Steffen \& Y.-A. Guillod (2004), Schweizerischer Baupreisindex Oktober 1998=100 Grundlagen, Neuchâtel.

G. Symeonidis (2000), Price Competition and Market Structure: The Impact of Cartel Policy on Concentration in the UK, Journal of Industrial Economics 48, 1-26.

J. Thompson, J. \& D. Kaserman (2001), After the Fall: Stock Price Movements and the Deterrence Effect of Antitrust Enforcement, Review of Industrial Organization 19, 329334.

C. Veljanovski (2007), Cartel Fines in Europe: Law, Practice and Deterrence, World Competition 29 , forthcoming.

G. Werden (2003), The Effect of Antitrust Policy on Consumer Welfare: What Crandall and Winston Overlook, Economic Analysis Group Working Paper, Antitrust Division, Washington D.C.

M. Whinston (2006), LECTURES ON ANTITRUST ECONOMICS, Cambridge.

World Bank (1999), A FRAMEWORK FOR THE DESIGN AND IMPLEMENTATION OF COMPETITION LAW AND POLICY, Washington D.C. 